\title{
Evaluation of Kasugamycin for Fire Blight Management, Effect on Nontarget Bacteria, and Assessment of Kasugamycin Resistance Potential in Erwinia amylovora
}

\author{
Gayle C. McGhee and George W. Sundin
}

Department of Plant Pathology, Michigan State University, East Lansing 48824.

Accepted for publication 24 September 2010.

\begin{abstract}
McGhee, G. C., and Sundin, G. W. 2011. Evaluation of kasugamycin for fire blight management, effect on nontarget bacteria, and assessment of kasugamycin resistance potential in Erwinia amylovora. Phytopathology 101:192-204.

The emergence and spread of streptomycin-resistant strains of Erwinia amylovora in Michigan has necessitated the evaluation of new compounds effective for fire blight control. The aminoglycoside antibiotic kasugamycin (Ks) targets the bacterial ribosome and is particularly active against E. amylovora. The efficacy of Ks formulated as Kasumin 2L for control of fire blight was evaluated in six experiments conducted over four field seasons in our experimental orchards in East Lansing, MI. Blossom blight control was statistically equivalent to the industry standard streptomycin in all experiments. E. amylovora populations remained constant on apple flower stigmas pretreated with Kasumin and were $\approx 100$-fold lower than on stigmas treated with water. Kasumin applied to apple trees in the field also resulted in a 100-fold reduced total culturable bacterial population compared with trees treated with water. We performed a prospective analysis of the potential for kasugamycin resistance $\left(\mathrm{Ks}^{\mathrm{R}}\right)$ development in E. amylovora which focused on spontaneous resistance development and acquisition of a transferrable $\mathrm{Ks}^{\mathrm{R}}$ gene. In replicated lab experiments, the development of spontaneous

resistance in E. amylovora to Ks at 250 or $500 \mathrm{ppm}$ was not observed when cells were directly plated on medium containing high concentrations of the antibiotic. However, exposure to increasing concentrations of Ks in media (initial concentration $25 \mu \mathrm{g} \mathrm{ml}^{-1}$ ) resulted in the selection of Ks resistance (at $150 \mu \mathrm{g} \mathrm{ml}^{-1}$ ) in the E. amylovora strains Ea110, Ea273, and Ea1189. Analysis of mutants indicated that they harbored mutations in the kasugamycin target $k s g A$ gene and that all mutants were impacted in relative fitness observable through a reduced growth rate in vitro and decreased virulence in immature pear fruit. The possible occurrence of a reservoir of $\mathrm{Ks}^{\mathrm{R}}$ genes in orchard environments was also examined. Culturable gram-negative bacteria were surveyed from six experimental apple orchards that had received at least one Kasumin application. In total, $401 \mathrm{Ks}^{\mathrm{R}}$ isolates (42 different species) were recovered from apple flowers and leaves and orchard soil samples. Although we have not established the presence of a transferrable $\mathrm{Ks}^{\mathrm{R}}$ gene in orchard bacteria, the frequency, number of species, and presence of $\mathrm{Ks}^{\mathrm{R}}$ enterobacterial species in orchard samples suggests the possible role of nontarget bacteria in the future transfer of a $\mathrm{Ks}^{\mathrm{R}}$ gene to $E$. amylovora. Our data confirm the importance of kasugamycin as an alternate antibiotic for fire blight management and lay the groundwork for the development and incorporation of resistance management strategies.
\end{abstract}

Fire blight, caused by the enterobacterial pathogen Erwinia amylovora, is a major disease problem and a limiting factor to apple and pear production in most regions of the world where these fruit are grown. On apple, blossom blight disease symptoms are typically initiated in the spring on flowers as overwintering inoculum from cankers is disseminated to the surface of stigmata by rain and insects (33). The pathogen grows as an epiphyte between the papillae on the stigma, and infection potential is most strongly influenced by flower age, temperature, and rainfall, which regulate bacterial population size $(35,36,42,50,51)$. Rain events or heavy dew facilitate the movement of pathogen cells from the stigma to the hypanthium where infection occurs through the floral nectaries (57). Thus, the flower and, in particular, the stigma is a site of pathogen multiplication, and also a site in which pathogen populations can be targeted by management strategies because of their epiphytic surface association in this habitat. Blossom blight control is also critical because successful infection enables the pathogen to multiply and spread internally in trees (inaccessible to bactericides) and allows further amplification of pathogen populations supplying inoculum for subsequent shoot blight infections.

Corresponding author: G. W. Sundin; E-mail address: sundin@msu.edu

doi:10.1094/PHYTO-04-10-0128

(c) 2011 The American Phytopathological Society
In the 1950s, the antibiotic streptomycin was first utilized for blossom blight control and proved highly efficacious (53). However, intensive use of this antibiotic resulted in the development of streptomycin resistance in E. amylovora populations, first in the western United States $(10,23,40)$ and then in Michigan and in other countries, including Canada, Israel, and New Zealand $(6,26,31,41,52)$. Alternatives to streptomycin include the antibiotic oxytetracycline (31,32), the biological control agent Serenade MAX, and antagonistic stigma-colonizing bacteria, including Pseudomonas fluorescens A506, Pantoea agglomerans C9-1, and $P$. agglomerans E325 $(17,37,49)$. None of these alternate materials is as effective as streptomycin in controlling blossom blight.

In the absence of host resistance, successful bacterial disease control often requires large reductions in population size or effective cessation of bacterial growth. Antibiotics represent the main class of materials currently known with the potential to achieve these required results and, thus, provide the best potential for controlling plant-pathogenic bacteria. However, the availability of antibiotics for plant agriculture is limited because most antibiotics are used in clinical medicine to protect against or cure bacterial infections in humans and are not used in plant agriculture. This restriction is mainly due to the occurrence of transferrable antibiotic resistance in bacterial populations and the negative impact of antibiotic resistance on controlling human infections (11). In contrast, the antibiotics that can be used in 
animal agriculture, both therapeutically and for growth promotion, overlap widely with those used in clinical medicine (19). This overlap is thought to be responsible for antibiotic resistance problems in human pathogens arising from either the transfer of antibiotic-resistant human-pathogenic bacteria from agricultural animals to humans or the transfer of antibiotic resistance genes from an animal agricultural reservoir to the human bacterial community (43).

Although most known streptomycin-resistant $\left(\mathrm{Sm}^{\mathrm{R}}\right)$ strains of E. amylovora are spontaneous mutants with a single nucleotide alteration in the chromosomal rps $L$ gene, the presence of the transferrable $s t r A-s t r B$ resistance genes on the transposon $\operatorname{Tn} 5393$ is the predominant mechanism of streptomycin resistance in $E$. amylovora strains isolated in Michigan and New York $(7,29,38)$. The Tn5393 transposon is widely distributed among other $\mathrm{Sm}^{\mathrm{R}}$ plant pathogens, including Pseudomonas syringae, that were isolated from plant hosts treated with streptomycin for bacterial disease control $(46,47)$. Tn5393 is also carried by nontarget phyllosphere bacteria isolated from orchards and ornamental tree nurseries where streptomycin was used for bacterial disease control $(7,48)$.

It was originally hypothesized in the medical literature that antibiotic use initially selects for resistance in nontarget bacteria inhabiting niches in close proximity to that of the target pathogens (21). These nontarget bacteria are then thought to transfer the resistance determinants into the target pathogen. This same route of transfer was hypothesized to occur in the evolution of streptomycin resistance in E. amylovora because the $\mathrm{Sm}^{\mathrm{R}}$ plasmid pEa34 encoding Tn5393 was thought to have been transferred from the orchard epiphyte Pantoea agglomerans into E. amylovora (7). Thus, any evaluations of new antibiotics for disease control must also include an examination of the effect of the antibiotic on nontarget bacteria and the potential for resistance development in both the pathogen and the nontarget populations.

Kasugamycin is an aminoglycoside antibiotic in the same class as streptomycin but with a different mode of action (9). Kasugamycin was originally developed as a fungicide to control rice blast caused by Pyricularia oryzae, and has also been evaluated as a bactericide and examined for fire blight control in the 1980s (34). Further testing of kasugamycin on apple was suspended until recently due to problems with phytotoxicity. The negative impact of streptomycin resistance resulting in disease control failures, and the lack of suitable alternatives, has necessitated a new assessment of the potential applicability of kasugamycin for fire blight management. We hypothesized that Kasumin 2L (Arysta Lifescience, Cary, NC), a different formulation than that used in past studies, would be efficacious against the blossom blight phase of fire blight and would represent a viable long-term alternative to streptomycin in plant disease control because of a lack of clinical or animal agriculture uses of this antibiotic. However, the risk of resistance development needed to be evaluated, from both the standpoint of the potential for spontaneous resistance mutations and the possibility of resistance gene transfer from nontarget orchard bacteria. In this study, we evaluated the efficacy of Kasumin for fire blight control, assessed the potential for the selection of spontaneous mutants of E. amylovora with resistance to kasugamycin, analyzed the effect of Kasumin on nontarget orchard bacteria, and surveyed apple flowers, leaves, and orchard soil for bacterial isolates with reduced sensitivity to kasugamycin to estimate the risk potential for the development of kasugamycin resistance in E. amylovora.

\section{MATERIALS AND METHODS}

Bacterial strains and growth media. A spontaneous rifampicin (Rif)-resistant mutant of E. amylovora Ea110 was used as pathogen inoculum in all field experiments. Strain Ea110 was isolated from a diseased apple tree in Michigan (31) and was stored in $15 \%$ glycerol at $-80^{\circ} \mathrm{C}$ prior to use. In laboratory experiments, we also used E. amylovora Ea273 and Ea1189; Ea273 was isolated in New York and the genome sequence of this strain has been determined (http://www.sanger.ac.uk/Projects/ E_amylovora/), and Ea1189 was isolated in Germany and we routinely use this strain for genetic studies (58). Each of the strains used in the studies was sensitive to kasugamycin and streptomycin. E. amylovora strains were grown in Luria Bertani (LB) medium at $28^{\circ} \mathrm{C}$ and apple orchard bacteria were isolated on King's medium B (KB) (24) with cycloheximide added at $50 \mu \mathrm{g}$ $\mathrm{ml}^{-1}$ to inhibit fungal growth. Antibiotics were added to media as necessary, including kasugamycin $\left(100,250\right.$, and $\left.500 \mu \mathrm{g} \mathrm{ml}^{-1}\right)$, Rif $\left(100 \mu \mathrm{g} \mathrm{ml}^{-1}\right)$, and streptomycin $\left(100 \mu \mathrm{g} \mathrm{ml}^{-1}\right)$.

Effect of Kasumin on $E$. amylovora populations on apple flower stigmas. Antibiotic treatments consisted of either a standard treatment (Agri-Mycin; 17\% streptomycin sulfate; Nufarm Americas, Burr Ridge, IL) or a kasugamycin treatment (Kasumin; Arysta LifeSciences). The nonionic surfactant Regulaid (Kalo Inc., Overland Park, KS) was used in antibiotic applications to aid in surface area coverage and increase penetration of the antibiotics into flower tissue, and for increased retention of antibiotics to plant material.

One-year-old shoots of apple cv. Gala with 5 to 10 king flowers open were removed from trees maintained in an East Lansing, MI orchard and transported to the laboratory. Tissue $(\approx 2.5 \mathrm{~cm})$ was trimmed from the base of each shoot, and groups of three shoots were then placed in floral foam saturated with water in 1-liter plastic containers. Bacterial inoculum consisted of $E$. amylovora Ea110 which was cultured overnight in $\mathrm{LB}$ at $28^{\circ} \mathrm{C}$. Bacterial cells were washed twice in sterile $0.5 \times$ phosphate buffered saline (PBS) and resuspended to a final concentration of $1 \times 10^{8} \mathrm{CFU}$ $\mathrm{ml}^{-1}$ in $0.5 \times \mathrm{PBS}+0.3 \%$ Tween 20 as a surfactant. Either $2 \mu \mathrm{l}$ of bacterial cells or $2 \mu \mathrm{l}$ of water as a control were pipetted directly onto the stigmatic surfaces of the king bloom within each flower cluster. The shoots with inoculated flowers were then incubated in a growth chamber at $27^{\circ} \mathrm{C}$ for $24 \mathrm{~h}$, after which $5 \mu \mathrm{l}$ of Kasumin $\left(100 \mu \mathrm{g} \mathrm{ml}^{-1}\right.$ solution $)+0.03 \%$ Regulaid, $5 \mu \mathrm{l}$ of Agrimycin $\left(100 \mu \mathrm{g} \mathrm{ml}^{-1}\right.$ solution $)+0.03 \%$ Regulaid, or $5 \mu \mathrm{l}$ of water + $0.03 \%$ Regulaid were pipetted directly onto the inoculated stigmas.

Treatments were placed randomly from available king flowers on each shoot and multiple treatments were placed on each shoot. Following a second incubation in a growth chamber at $27^{\circ} \mathrm{C}$ for $24 \mathrm{~h}$, individual stigmas were dissected from flowers, placed in 1 $\mathrm{ml}$ of $0.5 \times \mathrm{PBS}$, and sonicated for $1 \mathrm{~min}$ in an ultrasonic bath (model 250T; VWR Scientific, Houston). The solution remaining following sonication was serially diluted and appropriate dilutions were spread on LB + Rif agar plates. Plates were incubated at $27^{\circ} \mathrm{C}$ for $48 \mathrm{~h}$, after which the Ea110 colonies were enumerated. Two separate experiments were conducted. Statistical analyses of pooled $\log _{10}$-transformed population data from both experiments were done using a one-way analysis of variance (ANOVA), and mean separation $(P<0.05)$ was accomplished using Fisher's protected least significant difference test. We used the M-STAT-C 4.0 statistical research program (https://www.msu.edu/ freed/ mstatc.htm) for all statistical analyses of data from this study.

A second set of experiments was conducted in which the antibiotics were applied to stigmas prior to the bacterial inoculum. The apple shoots and bacterial inoculum were prepared as described above. In these experiments, apple flowers on the shoots were sprayed to runoff with a solution of either Kasumin at $100 \mu \mathrm{g} \mathrm{m} \mathrm{l}^{-1}+0.03 \%$ Regulaid, Agri-Mycin at $100 \mu \mathrm{g} \mathrm{ml}^{-1}+$ $0.03 \%$ Regulaid, or $0.03 \%$ Regulaid as a control. The shoots were allowed to dry for $30 \mathrm{~min}$ in a laminar flow hood, after which stigmas from king flowers were inoculated with $2 \mu$ lof cells of $E$. amylovora Ea110 $\left(1 \times 10^{8} \mathrm{CFU} \mathrm{ml}^{-1}\right)$. The bacterial inoculum was allowed to dry on stigmas for $10 \mathrm{~min}$ before a time $0(\mathrm{~T}=0)$ sample was taken. The five stigmas from each king flower were 
then dissected out of each flower, placed in $1 \mathrm{ml}$ of sterile $0.5 \times$ PBS, and sonicated for $1 \mathrm{~min}$. The solution remaining following sonication was diluted and plated on LB + Rif agar. Time points for sampling were at $\mathrm{T}=0,6$, and $24 \mathrm{~h}$ postinoculation. Five flowers per time point for each treatment were removed and a mean of stigma populations for each of the five stigmas harvested was used to generate population data. This experiment was conducted twice. Statistical analyses of pooled $\log _{10}$-transformed population data from both experiments were done using a oneway ANOVA, and mean separation $(P<0.05)$ was accomplished using Fisher's protected least significant difference test.

Efficacy experiment plot design: inoculum preparation, pathogen inoculation, treatment applications, and disease assessment. Six field experiments designed to test the efficacy of antibiotics for blossom blight control were conducted over the course of 4 years in experimental orchards located in East Lansing, MI. The orchards consisted of blocks of $\approx 50$ to 100 apple trees of either cv. Jonathan grafted on MM.106 rootstock or cv. Gala grafted on M.9 rootstock. Antibiotic treatments were applied to trees $\approx 24 \mathrm{~h}$ prior to or $24 \mathrm{~h}$ following inoculation, or both, with E. amylovora Ea110. Treatments were arranged in a randomized complete block design with five single-tree replicates per treatment. Disease incidence data from each individual experiment were arcsine-transformed and analyzed using ANOVA, and mean separation $(P<0.05)$ was accomplished using Fisher's protected least significant difference test.

Bacterial cultures of E. amylovora Ea110 cells for field inoculations were grown in $\mathrm{LB}$ broth at 27 to $28^{\circ} \mathrm{C}$ to late logearly stationary phase. Cell suspensions were adjusted turbidimetrically to the desired cell density $\left(10^{6}\right.$ to $\left.10^{7} \mathrm{CFU} \mathrm{ml}{ }^{-1}\right)$ in $0.5 \times$ sterile PBS and kept on ice during transfer to the field and prior to inoculations. Apple trees were inoculated by spraying flower clusters around the perimeter of each tree with the $E$. amylovora Ea110 cell suspension. An 11.4-liter pump mist sprayer (Solo, Newport News, VA) was used for the inoculations. Inoculation occurred at full bloom during the evening to ensure conditions favorable for bacterial survival.

All field experiments included a control treatment (nontreated, pathogen-inoculated trees), a standard treatment (Agri-Mycin + $0.03 \%$ Regulaid, pathogen-inoculated trees), and kasugamycin treatments (Kasumin $+0.03 \%$ Regulaid, pathogen-inoculated trees). Antibiotic treatments were applied with a handgun sprayer at $24.6 \mathrm{~kg} / \mathrm{cm}^{2}$ and 2,800 liters of water per hectare. Application timings were generally at full bloom. Following a sufficient duration to allow blossom blight infection to occur (usually $\approx 28$ days), trees were rated for the incidence of blossom blight symptoms by counting the number of flower clusters with blossom blight strikes in a random sample of 210 flower clusters per tree. A cluster was considered infected if one or more flowers exhibited fire blight symptoms.

Experiment 1 was conducted in 2006 with antibiotic application timings on 3 and 5 May and pathogen inoculation on 4 May. Experiments 2 and 3 were conducted in 2007 in two separate blocks of apple cv. Jonathan trees with antibiotic application timings on 4 and 7 May and pathogen inoculation on 6 May. Experiment 4 was conducted in 2008 with antibiotic application timings on 8 and 12 May and pathogen inoculation on 10 May. Experiment 5 was conducted in 2008 with antibiotic application timings on 5 and 7 May and pathogen inoculation on 6 May. Experiment 6 was conducted in 2009 with pathogen inoculation on 7 May and antibiotic application on 8 May. Pathogen inoculum consisted of suspensions of E. amylovora Ea110 in water at a concentration of $10^{7} \mathrm{CFU} / \mathrm{ml}$ (experiments 1, 4, 5, and 6) or $10^{6} \mathrm{CFU} / \mathrm{ml}$ (experiments 2 and 3 ).

Effect of Kasumin on nontarget bacteria inhabiting apple flowers and leaves. The effect of Kasumin on population size of nontarget bacteria on apple flowers and leaves was evaluated with a field experiment conducted in 2008 and 2009. Four single-tree replicates of apple cv. Jonathan grafted on MM.106 rootstock were used for each treatment. All field experiments included a control treatment (water), a standard treatment (Agri-Mycin at $100 \mathrm{ppm}$ ), and a kasugamycin treatment (Kasumin at $100 \mathrm{ppm}$ ). All treatments were applied with a handgun sprayer at $24.6 \mathrm{~kg} / \mathrm{cm}^{2}$ and 2,800 liters of water per hectare. A single application was done at full bloom. Flower samples for bacterial population analysis were collected immediately prior to antibiotic application and 1 week after application. Leaf samples were collected 2 weeks after antibiotic application. Flower sample replicates consisted of 25 flowers from each of five trees (25 total flowers per replicated sample). Five samples were collected from each orchard. Leaf samples were taken similarly, except one leaf sample consisted of 25 leaves.

All samples were placed on ice in coolers for return to the laboratory and maintained at $4{ }^{\circ} \mathrm{C}$ in the laboratory. Individual flower samples (25 flowers) were weighed and placed into 25 or $50 \mathrm{ml}$ of sterile PBS and shaken vigorously by hand for $1 \mathrm{~min}$. Appropriate serial dilutions from this suspension were spread onto $\mathrm{KB}$ medium amended with cycloheximide at $50 \mu \mathrm{g} \mathrm{m}{ }^{-1}$ $(\mathrm{KBc})$ for population analysis of total culturable bacteria. Individual leaf samples were cut into $2.5-\mathrm{cm}$ strips, placed in a plastic bag, and shaken to mix. From each of the five leaf samples, $2 \mathrm{~g}$ was placed in $20 \mathrm{ml}$ of chilled $0.5 \times$ PBS and sonicated for $7 \mathrm{~min}$ in an ultrasonic bath. Samples $(0.1 \mathrm{ml})$ from appropriate serial dilutions of the sonicated solution were spread on $\mathrm{KBc}$ and on $\mathrm{KBc}$ also amended with kasugamycin at $100 \mu \mathrm{g} \mathrm{ml}^{-1}$ (KBksc). All population data were $\log _{10}$-transformed and data from both experiments were pooled prior to statistical analyses. An ANOVA was run, and mean separation $(P<0.05)$ was accomplished using Fisher's protected least significant difference test and the MSTAT-C 4.0 program. Data were analyzed for differences between sampling times within each treatment, and the effect of different treatments on population size was also assessed per each sampling time.

Isolation and identification of kasugamycin-resistant nontarget bacteria from apple orchards. We sampled flowers, leaves, and soil from five apple orchards in Michigan. Flower and soil samples were taken from two of the orchards prior to application of Kasumin to trees. Following application of Kasumin, leaf samples were taken from three orchards and soil samples were taken from all five orchards. All samples were chosen randomly from the orchards. Flower and leaf samples were collected and processed as described above. Soil samples consisted of five bulked soil cores $(\approx 7.5 \mathrm{~cm}$ in depth) taken from under the dripline of trees; five samples were taken per orchard. From each of five soil cores composing a sample, $2 \mathrm{~g}$ was bulked and transferred into $20 \mathrm{ml}$ of chilled $0.5 \times$ PBS and sonicated for $7 \mathrm{~min}$ in an ultrasonic bath (model 250T; VWR Scientific). Samples $(0.1 \mathrm{ml})$ from appropriate serial dilutions of the sonicate were spread on $\mathrm{KBc}$ and KBksc. All incubations of culture plates were done at $28^{\circ} \mathrm{C}$ for $72 \mathrm{~h}$ following which bacterial colonies were counted.

After bacterial colonies were counted on plates, a sample of colonies was selected for analysis from both $\mathrm{KBc}$ and $\mathrm{KBksc}$. The colonies selected from $\mathrm{KBc}$ were included to obtain a small representation of genera present on flowers and leaf surfaces because very few of these organisms were recovered on KBksc. Colony selection was done randomly; however, we also attempted to select a variety of colony morphologies. Bacteria were initially screened using the rapid gram-reaction test in $3 \% \mathrm{KOH}$ to detect gram-negative colonies (39). In total, 588 presumptive gramnegative colonies were recovered for further analysis, purified by single-colony streaking, and stored in $15 \%$ glycerol at $-70^{\circ} \mathrm{C}$.

We sequenced a portion of the $16 \mathrm{~S}$ rDNA for identification analysis (8). Genomic DNA preps were done on each isolate by boiling for $15 \mathrm{~min}$ in a lysis buffer $(0.5 \mathrm{M} \mathrm{KCl}, 0.01 \mathrm{M}$ Tris- $\mathrm{HCl}$ [pH 8.5], and 1\% Tween20). The lysate was used as template in PCR reactions. Forward primer 63f (5'-CAG GCC TAA CAC 
ATG CAA GTC-3') and reverse primer 1387r (5'-GGG CGG WGT GTA CAA GGC-3') were used to amplify $\approx 1,300 \mathrm{bp}$ of the bacterial 16S rRNA gene as described by Marchesi et al. (27). Amplified products were purified using the QIAquick PCR Purification Kit (Qiagen; Valencia, CA) and sequenced. All sequencing was performed at the Michigan State University Department of Energy Plant Research Laboratory sequencing facility using ABI dye-terminator chemistry and an ABI 3730 genetic analyzer (Applied Biosystems, Foster City, CA). Sequence analysis was conducted using BLASTN version 2.2.18 at the National Center for Biotechnology Information website (http://www.ncbi.nlm.nih. gov/blast).

Selection of spontaneous kasugamycin resistance and genetic basis of resistance. Two separate experiments were designed to determine whether E. amylovora could develop spontaneous kasugamycin resistance. In the first experiment, $E$. amylovora strains Ea110, Ea1189, and Ea273 were each grown overnight in LB broth, diluted 10-fold in $0.5 \times$ PBS, and plated onto LB containing kasugamycin (LBks) at either 100, 250, or $500 \mu \mathrm{g} \mathrm{ml}{ }^{-1}$. In addition, cells were plated on LB containing streptomycin at $100 \mu \mathrm{g} \mathrm{ml}^{-1}$ as a control. The plates were incubated for $48 \mathrm{~h}$ at $24^{\circ} \mathrm{C}$ in the dark prior to visual examination for the occurrence of resistant colonies. Plates were also reexamined after $120 \mathrm{~h}$ of incubation. This experiment was repeated three times for each strain.

In the second experiment, E. amylovora strains Ea110, Ea1189, and Ea273 were each grown overnight in LB broth, and then subcultured into fresh LB broth medium amended with kasugamycin at $25 \mu \mathrm{g} \mathrm{ml}^{-1}$. If the strain was able to grow in the kasugamycin concentration it was exposed to, cells were subcultured to a progressively higher kasugamycin concentration every $24 \mathrm{~h}$. If the cells were unable to grow, they were passaged in the same antibiotic concentration until they were able to acclimate to the antibiotic level. In this manner, E. amylovora strains were gradually exposed to levels of kasugamycin at 25, 50, $100,125,150,175$, and $200 \mu \mathrm{g} \mathrm{ml}^{-1}$. This process was continued until the strain could grow and form colonies on LBks amended with kasugamycin at $150 \mu \mathrm{g} \mathrm{ml}^{-1}$. All strains capable of growth on LBks were also assayed for resistance to streptomycin on LB containing streptomycin at $100 \mu \mathrm{g} \mathrm{ml}^{-1}$.

The ksgA gene, a known target for kasugamycin in Escherichia coli, was isolated using PCR and sequenced for any Erwinia amylovora strain growing on LB containing kasugamycin at 150 $\mu \mathrm{g} \mathrm{ml}{ }^{-1}$. Mutation of $k s g A$ has been previously shown to be a genetic determinant of resistance (55) because the KsgA protein functions in the methylation of the ribosome. As described above, genomic DNA from kasugamycin-resistant $\left(\mathrm{Ks}^{\mathrm{R}}\right)$ and wild-type $E$. amylovora was boiled for $15 \mathrm{~min}$ in lysis buffer (0.5 M KCL, 0.01 $\mathrm{M}$ Tris- $\mathrm{HCl}$ [pH 8.5], and 1\% Tween 20). The lysate was used as template in PCR reactions. Forward primer KsgA-F (5'ATCAGGGGCTTCCGGTGCTAAAT) and reverse primer KsgAR (5'-AATATGCGGCTGTTCTCCCACCAC) were developed from the $E$. amylovora genome (http://www.sanger.ac.uk/ Projects/E_amylovora) to amplify a 1,232-bp fragment of the $E$. amylovora chromosome containing the $k s g A$ gene. Amplified products were purified using the QIAquick PCR Purification Kit (Qiagen) and sequenced at the Michigan State University Gene Technology Sequencing Facility using ABI dye-terminator chemistry and an ABI 3730 genetic analyzer (Applied Biosystems). Sequence analysis was conducted using the Lasergene suite of software.

Relative fitness of spontaneous $\mathrm{Ks}^{\mathrm{R}}$ mutants of $E$. amylovora. Experiments were conducted to compare the virulence of newly evolved spontaneous $\mathrm{Ks}^{\mathrm{R}}$ E. amylovora strains with their wild-type kasugamycin-susceptible $\left(\mathrm{Ks}^{\mathrm{S}}\right)$ ancestral strains. Virulence assays using 10 replicate immature pear fruit per strain per experiment were performed essentially as described previously (5), except a 5 - $\mu$ l inoculum dose $\left(1 \times 10^{8} \mathrm{CFU} / \mathrm{ml}\right)$ was used.
Following inoculation, pear fruit were incubated in a humidified chamber for 7 days at $28^{\circ} \mathrm{C}$. In similar virulence experiments, bacterial population size was assessed over the first 3 days after inoculation using destructive sampling. Necrotic lesion size was measured each day beginning on day 2 after inoculation and continuing through day 7 . Two replicate experiments were conducted for each strain. Statistical analyses of lesion size data pooled from two experiments were done using a one-way ANOVA; pooled data values for each day were analyzed separately. Mean separation $(P<0.05)$ was accomplished using Fisher's protected least significant difference test.

Fitness experiments comparing bacterial populations of newly evolved $\mathrm{Ks}^{\mathrm{R}}$ E. amylovora strains with their wild-type $\mathrm{Ks}^{\mathrm{S}}$ ancestral strains were conducted separately from the virulence study using 20 replicate immature pear fruit per strain per experiment. Following inoculation as described above, five replicate pear fruit were destructively sampled per treatment for the day 0 time point prior to pear fruit being incubated in a humidified chamber for 4 days. Briefly, each day for days 0 to 3 after inoculation, five pear replicates were randomly selected for analysis. Using a no. 2 sterile cork borer calibrated to a depth of $1 \mathrm{~cm}$, pear tissue plugs taken from the inoculation site were removed and placed individually into $450 \mu \mathrm{l}$ of $0.5 \times$ PBS in a $1.5-\mathrm{ml}$ microfuge tube and ground to release bacteria from pear tissue. The homogenized pear tissue-PBS slurry was allowed to soak for $30 \mathrm{~min}$ to maximize bacterial release from tissue before appropriate serial dilutions were plated onto either LB (for wildtype controls) or LBks agar. This experiment was repeated twice per strain tested. In each experiment, the control was run concurrently with the mutant strain tested. Population data were $\log _{10}$-transformed prior to analysis. Replicate data for each time point were pooled from both experiments, and populations means and standard error of the means were calculated.

The in vitro growth rate of the newly evolved $\mathrm{Ks}^{\mathrm{R}}$ E. amylovora strains was also compared with that of their wild-type ancestor in minimal medium (MM) (28) and LB broth. All bacteria were grown overnight in LB broth, diluted 1:10 in $0.5 \times$ PBS, and then diluted 1:100 in either MM or LB broth. Diluted bacterial suspension in media $(2 \mathrm{ml})$ was placed in three replicate wells of a sterile 24-well microtiter plate (Evergreen Scientific, Los Angeles) and sealed with the Breathe-Easy gas permeable sealing membrane, regular strength (Diversified Biotech, Boston, MA). Sealed plates were then placed in a Tecan Safire plate reader (Tecan, Durham, NC). Optical readings were taken every 5 min using a wavelength of $600 \mathrm{~nm}$, with $30 \mathrm{~s}$ of shaking at $2.5 \mathrm{~min}$ and prior to each read. Cultures were allowed to settle for $10 \mathrm{~s}$ after shaking and before optical density measurements were taken. Readings were taken for $24 \mathrm{~h}$ for LB cultures and $36 \mathrm{~h}$ for MM cultures. Media and well blanks were also included in each run.

Optical density at $600 \mathrm{~nm}\left(\mathrm{OD}_{600}\right)$ values from growth curves were standardized by dividing by the initial $\mathrm{OD}_{600}(0 \mathrm{~h})$ and then $\log _{2}$ transformed. The transformed values were plotted and the window of exponential growth was identified by linear regression. Lag time was calculated simply as the $x$-intercept of the linear equation (20).

Doubling time $(g)$ was determined by the equation $g=$ $3.3\left[\log _{10}(N 2)-\log _{10}(N 1)\right] / t$, where $N 1$ and $N 2$ are the original nontransformed $\mathrm{OD}_{600}$ values corresponding to the window of exponential growth observed in the $\log _{2}$ transformation plot and $t$ is the time interval between them (25). Values for both lag time and doubling time were compared by two-tailed paired $t$ tests.

Differential sensitivity of bacteria to kasugamycin and Kasumin. During this work, we discovered that many bacterial isolates examined appeared to be more susceptible to the formulated product Kasumin than to kasugamycin, when either material was added to media to yield equivalent concentrations of kasugamycin. To further investigate this observation, a subset of 
55 isolates both sensitive and exhibiting varying levels of kasugamycin resistance were selected from the 588 environmental isolates originally screened for kasugamycin resistance. We also examined the sensitivity of a collection of $18 \mathrm{E}$. amylovora, $1 \mathrm{E}$. pyrifoliae, and 1 Erwinia sp. strains which included E. amylovora Ea110, Ea273, and Ea1189 and the additional strains Al-1, Be-A8, Bcn20, CA11, Ea88, Ea322, EL01, IH3-1, LebA19, MA-1, MI51, MR1, OR25, S5, and UtRJ2 $(12,26,29)$ and E. pyrifoliae Ep1/96 (26) and Erwinia sp. Ejp557 (28). Nine of the E. amylovora strains were resistant to streptomycin, either via a spontaneous mutation or through acquisition of $\operatorname{Tn} 5393(12,28,31)$. Bacterial growth was assessed on KB medium containing either Kasumin (containing 2\% kasugamycin) or technical-grade kasugamycin (Sigma-Aldrich, St. Louis), with both at concentrations of 100,250 , and $500 \mu \mathrm{g} \mathrm{ml} \mathrm{m}^{-1}$. In addition, we obtained the formulation blank (Kasumin formulation without kasugamycin) of Kasumin (KFB) from Dr. V. J. Spadafora (Arysta LifeScience), and equivalent volumes of the blank (relative to the volume of Kasumin to generate concentrations of 100,250 , and $500 \mu \mathrm{g} \mathrm{ml}^{-1}$ ) were added to media as well. Growth was evaluated visually after 2 days of incubation at $28^{\circ} \mathrm{C}$ in the dark and again after 5 days for slower-growing bacteria. Cultures were considered negative for growth if, after 2 or 5 days, vigorous growth was observed on the unamended $\mathrm{KB}$ plate and no growth was observed on the test plate.

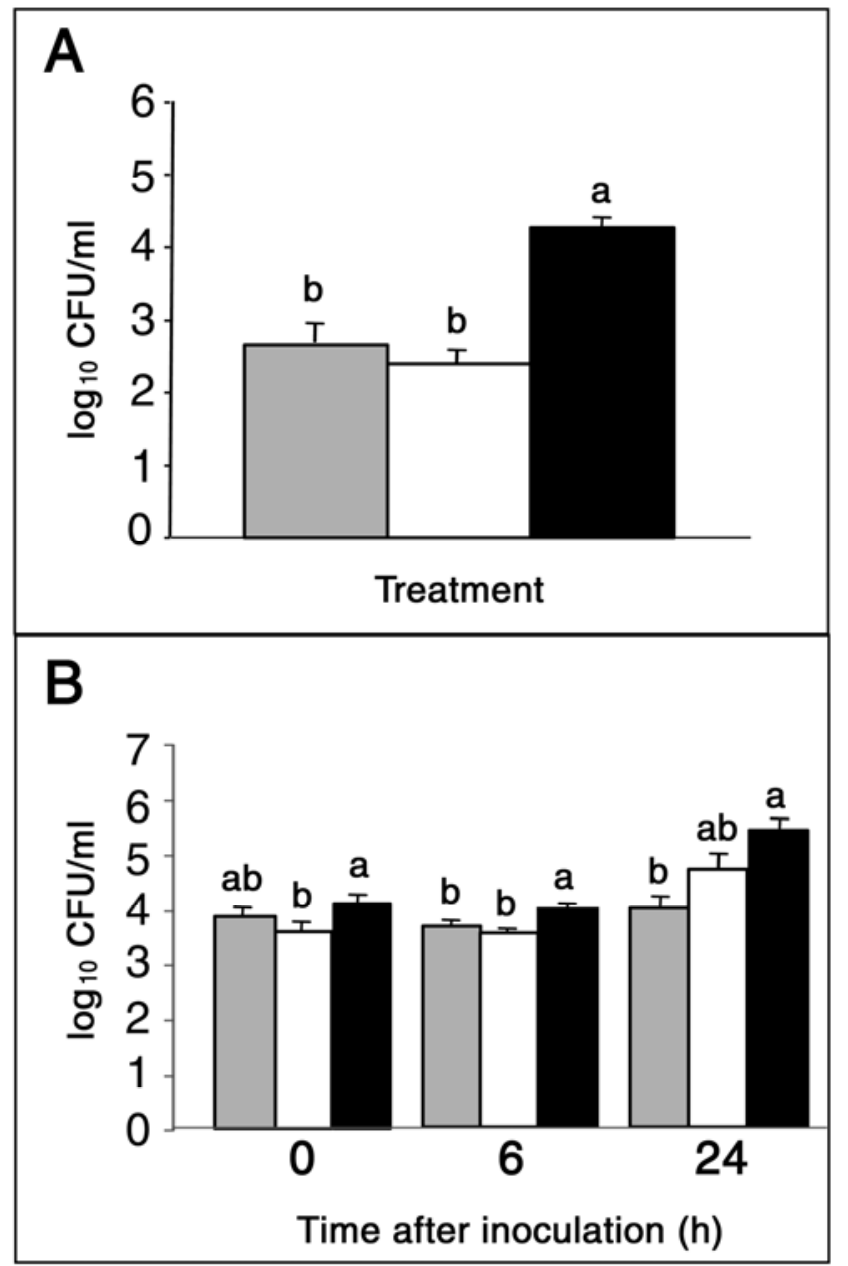

Fig. 1. Survival of Erwinia amylovora Ea110 on apple flower stigmas when A, the bacteria were inoculated $24 \mathrm{~h}$ prior to antibiotic application or $\mathbf{B}$, antibiotics were applied prior to bacterial inoculation. Treatments are: Kasumin (gray bars), Agri-Mycin (white bars), and water (black bars). The presence of different letters above the bars at each isolation point indicates that the treatment means are significantly different $(P<0.05)$ according to Fisher's protected least significant difference test.

\section{RESULTS}

Effect of Kasumin on $E$. amylovora populations on apple flower stigmas in vitro. The effect of Kasumin or streptomycin on E. amylovora populations on apple stigmas was evaluated either with the antibiotics applied $24 \mathrm{~h}$ after E. amylovora inoculation or applied immediately prior to E. amylovora inoculation. In the first set of experiments, antibiotics were added $24 \mathrm{~h}$ after Ea110 inoculation and populations were determined after an additional $24 \mathrm{~h}$ of incubation. An examination of data pooled from two separate experiments shows that Ea110 populations on water-treated stigmas were almost 100 -fold larger and significantly different than those on Kasumin-treated or streptomycintreated stigmas (Fig. 1A). When antibiotics were applied immediately prior to E. amylovora inoculation, populations of Ea110 on apple stigmas remained steady after $6 \mathrm{~h}$ and increased $\approx 10$-fold after $24 \mathrm{~h}$ of incubation on streptomycin-treated stigmas (Fig. 1B). Although Ea110 populations on water-treated stigmas also were similar after $6 \mathrm{~h}$, these populations increased $\approx 30$-fold after $24 \mathrm{~h}$ and were significantly larger than populations on stigmas treated with Kasumin (Fig. 1B).

Efficacy of Kasumin in blossom blight control. Incidence of fire blight disease, as measured by the occurrence of blossom blight symptoms in inoculated plots, was 35.6 to $72.5 \%$ infection in nontreated control trees in six experiments conducted between 2006 and 2009 (Table 1). Application of Kasumin to trees at least $24 \mathrm{~h}$ prior to and at least $24 \mathrm{~h}$ following inoculation with the virulent E. amylovora strain Ea110 resulted in high levels of disease control that were not significantly different from the standard Agri-Mycin treatment in all five experiments (Table 1). In three other experiments, Kasumin was not applied prior to but only applied following Ea110 inoculation. Similar results were observed in comparison with experimental treatments with two Kasumin applications, with disease control levels as high as $96 \%$ (Table 1). In one of the experiments comparing the efficacy of Kasumin with Agri-Mycin when both were applied after Ea110 inoculation, control with Agri-Mycin was significantly different than Kasumin (Table 1).

Effect of Kasumin on population size of nontarget bacteria inhabiting apple flowers and leaves. Bacterial populations increased $>100$-fold on apple flowers that were sprayed with water whereas populations increased only slightly on flowers sprayed with Kasumin (Fig. 2). In contrast, populations also increased 100-fold on flowers sprayed with Agri-Mycin (Fig. 2). Postapplication bacterial populations on flowers were significantly larger in the water and Agri-Mycin treatments compared with the Kasumin treatment (Fig. 2). Leaf populations were not significantly different from all treatments. Within treatments, the application of water or Agri-Mycin resulted in a significant increase in bacterial populations on flowers, whereas the application of Kasumin did not result in any difference in bacterial population size on flowers (Fig. 2).

Isolation and identification of $\mathrm{Ks}^{\mathrm{R}}$ bacteria from apple orchards. In total, between 2007 and 2009, 588 gram-negative bacteria were recovered from six experimental apple orchards in Michigan where Kasumin has been applied at least once. Isolates were initially chosen randomly from bacterial colonies growing on LB isolation plates from apple flower or leaf or orchard soil samples. Of these, 401 isolates $(68.2 \%)$ were capable of growth on LBks at levels of 100 to $500 \mu \mathrm{g} \mathrm{m}{ }^{-1}$ and were defined as resistant to kasugamycin (Table 2). A greater frequency of isolates from orchard soil (103 of 204; 50.5\%) exhibited high-level resistance to kasugamycin with growth on LBks at $500 \mu \mathrm{g} \mathrm{m} \mathrm{m}^{-1}$ compared with flower and leaf isolates (71 of 384; 18.5\%) (Table 2 ). Identification of bacteria was accomplished using sequence analysis of the conserved 16S rRNA gene and the identified organisms were differentiated as Enterobacteriaceae (closely related to E. amylovora) or other gram-negative bacteria. In total, 
six E. amylovora isolates were also recovered during this orchard sampling experiment, and all were found to be sensitive to kasugamycin (Table 3).

The most common bacterial species isolated from apple flowers and leaves in this study were Pantoea agglomerans $(59.2 \%$ of total enterobacterial isolates), Pseudomonas graminis, $P$. fluorescens, and Stenotrophomonas maltophilia (Table 3). Pseudomonas spp. composed $42.9 \%$ of all bacteria isolated in this study. Analysis of the growth of the various isolates on LBks medium amended with kasugamycin at either 100,250 , or $500 \mu \mathrm{g} \mathrm{ml}^{-1}$ revealed that $50.5 \%$ (52 of 103) of the enterobacterial isolates and $72.0 \%$ (349 of 485 ) of the other gram-negative isolates were resistant to kasugamycin. The most frequently isolated organism exhibiting high level Ks resistance was $S$. maltophilia while $P$. fluorescens and Pseudomonas spp. contained the most isolates with intermediate $\left(250 \mu \mathrm{g} \mathrm{ml}^{-1}\right)$ resistance (Table 3). The predominance of any particular $\mathrm{Ks}^{\mathrm{R}}$ genus varied by site and by year, indicating inherent variability in microbial communities based on geography and environmental factors (data not shown). Of potential concern were species such as Pantoea agglomerans, Pseudomonas fluorescens, and P. syringae that contained both $\mathrm{Ks}^{\mathrm{S}}$ and $\mathrm{Ks}^{\mathrm{R}}$ individuals (Table 3), indicating the possible acquisition of a kasugamycin resistance gene.

An assessment of the phenotype of sensitivity or resistance to kasugamycin combined with sensitivity or resistance to streptomycin was also done for the 588 identified gram-negative isolates. In all, $49.0 \%$ of isolates (288 of 588) were resistant to both antibiotics and $18.9 \%$ (111 of 588) were resistant to kasugamycin and sensitive to streptomycin (Table 4). In total, $21.8 \%$ of the bacterial isolates were sensitive to kasugamycin and resistant to streptomycin (Table 4). The $\mathrm{Ks}^{\mathrm{R}} \mathrm{Sm}^{\mathrm{R}}$ multiresistance phenotype was present in isolates from flowers, leaves, and soil and found in all major bacterial groups identified in this study (Table 4).

Selection of spontaneous kasugamycin resistance in $\boldsymbol{E}$. amylovora and genetic basis of resistance. In replicated experiments, E. amylovora was evaluated for the development of spontaneous resistance to kasugamycin. When wild-type E. amylovora strains Ea110, Ea1189, and Ea273 were grown overnight in broth culture and then directly plated onto LBks plates containing kasugamycin at either 100,250 , or $500 \mu \mathrm{g} \mathrm{ml}^{-1}$, no resistant colonies were identified following $48 \mathrm{~h}$ of incubation. After $120 \mathrm{~h}$, E. amylovora colonies did appear as pinpoint colonies. When these pinpoint colonies were subsequently transferred to new LBks plates with the identical level of kasugamycin, no colony growth was observed. This lack of growth on new plates indicated that the growth observed was the result of breakdown of kasugamycin in the media rather than spontaneously-resistant E. amylovora colonies.
Because $\mathrm{Ks}^{\mathrm{R}}$ colonies were not recovered using a traditional method to select for spontaneous antibiotic resistance, we decided to also use an alternate approach. In this method, we initially seeded three replicate broth cultures of LBks containing kasugamycin at $25 \mu \mathrm{g} \mathrm{ml}^{-1}$ with E. amylovora Ea110, Ea1189, or Ea273. After overnight incubation, a level of growth was observed in each of the broth tubes that was reduced compared with growth in unamended LB broth (data not shown). These cells were exposed

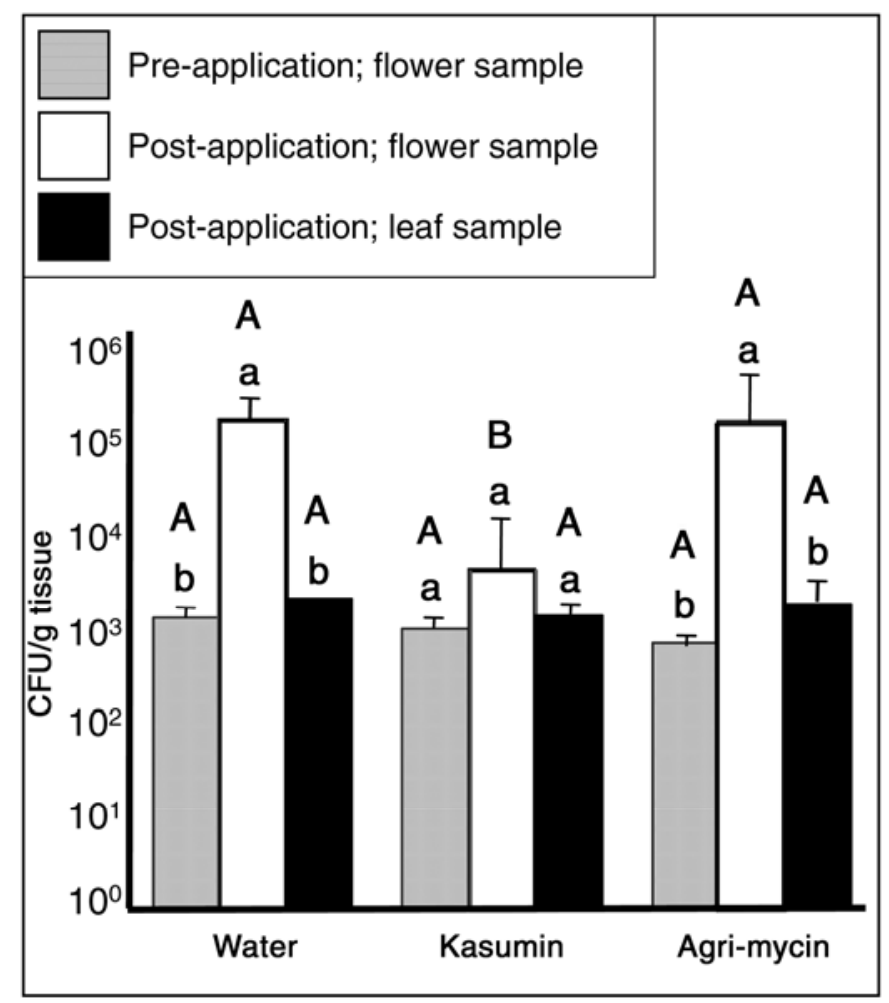

Fig. 2. Population size of total culturable bacteria isolated from apple flowers or leaves prior to and following application of Kasumin, Agri-Mycin, or water to trees. Population means (with standard error) consist of results from five individual tree replicates per treatment. The presence of different small letters above the bars indicates that the means within a treatment are significantly different $(P<0.05)$ according to Fisher's protected least significant difference test. The presence of different capital letters above the bars indicates that the means among treatments at a particular sampling time are significantly different $(P<0.05)$ according to Fisher's protected least significant difference test.

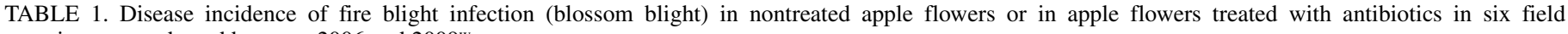
experiments conducted between 2006 and $2009^{\mathrm{w}}$

\begin{tabular}{|c|c|c|c|c|c|c|c|c|}
\hline \multirow[b]{2}{*}{ Exp, cultivar ${ }^{\mathrm{x}}$} & \multicolumn{3}{|c|}{ Application timings ${ }^{y}$} & \multirow{2}{*}{$\frac{\text { Nontreated control }}{\text { Infected }(\%)^{\mathrm{z}}}$} & \multicolumn{2}{|c|}{ Kasumin } & \multicolumn{2}{|c|}{ Agri-Mycin } \\
\hline & $25-50 \%$ & $70-80 \%$ & $100 \%$ & & Infected $(\%)^{\mathrm{z}}$ & Control (\%) & Infected $(\%)^{\mathrm{z}}$ & Control $(\%)$ \\
\hline 1, Gala & $X$ & $\ldots$ & $\mathrm{X}$ & $36.0 \mathrm{a}$ & $5.6 \mathrm{~b}$ & 84 & $2.9 \mathrm{~b}$ & 92 \\
\hline 2, Jonathan & $\mathrm{X}$ & $\ldots$ & $\mathrm{X}$ & $66.5 \mathrm{a}$ & $4.1 \mathrm{~b}$ & 94 & $3.5 \mathrm{~b}$ & 95 \\
\hline 3, Jonathan & $X$ & $\ldots$ & $X$ & $44.4 \mathrm{a}$ & $1.5 \mathrm{~b}$ & 97 & $0.2 \mathrm{~b}$ & 99 \\
\hline & $\ldots$ & $\ldots$ & $\mathrm{X}$ & $44.4 \mathrm{a}$ & $3.3 \mathrm{~b}$ & 93 & nd & nd \\
\hline 4, Gala & $\ldots$ & $\mathrm{X}$ & $X$ & $35.6 \mathrm{a}$ & $5.0 \mathrm{~b}$ & 86 & $1.2 \mathrm{~b}$ & 97 \\
\hline 5 , Jonathan & $\ldots$ & $X$ & $X$ & $44.3 \mathrm{a}$ & $2.0 \mathrm{~b}$ & 96 & $0.6 \mathrm{~b}$ & 99 \\
\hline & $\ldots$ & $\ldots$ & $X$ & $44.3 \mathrm{a}$ & $1.6 \mathrm{~b}$ & 96 & $0.3 \mathrm{~b}$ & 99 \\
\hline 6 , Jonathan & $\ldots$ & $\ldots$ & $X$ & $72.5 \mathrm{a}$ & $9.1 \mathrm{c}$ & 87 & $1.4 \mathrm{~b}$ & 98 \\
\hline
\end{tabular}

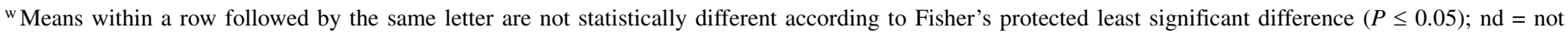
done.

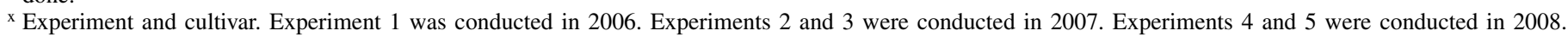
Experiment 6 was conducted in 2009. Pathogen inoculum consisted of suspensions of Erwinia amylovora Ea110 in water at a concentration of $10^{7}$ CFU/ml (experiments $1,4,5$, and 6) or $10^{6} \mathrm{CFU} / \mathrm{ml}$ (experiments 2 and 3 ).

y Materials were applied to trees when the listed percentage of blossoms were open.

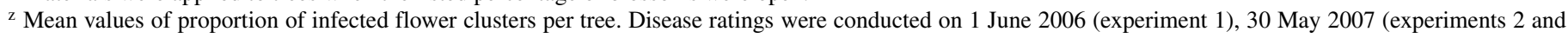

3), 3 June 2008 (experiments 4 and 5), and 12 June 2009 (experiment 6). 
to gradually increasing rates of kasugamycin over time in LBks broth and, by the conclusion of the 7-day experiment, each of the three E. amylovora strains were capable of forming colonies on LBks medium containing kasugamycin at $150 \mu \mathrm{g} \mathrm{ml}^{-1}$. We then amplified and sequenced the $k s g A$ target gene from each putative $\mathrm{Ks}^{\mathrm{R}}$ mutant and identified sequence alterations in each strain compared with the wild-type $k s g A$ sequence of strain Ea273

TABLE 2. Numerical distribution of gram-negative bacterial isolates recovered from apple flowers and leaves and apple orchard soil by kasugamycin resistance phenotype and year of isolation

\begin{tabular}{lccccc}
\hline & & \multicolumn{5}{c}{ No. of isolates } \\
\cline { 3 - 6 } Year, source & Total $^{\mathrm{y}}$ & Sensitive & Low & Intermediate & High \\
\hline 2007 & & & & & \\
Flower & 6 & 0 & 3 & 0 & 3 \\
Leaf & 7 & 3 & NT & 2 & 2 \\
Soil & 123 & 60 & NT & 8 & 55 \\
2008 & & & & & \\
Flower & 114 & 47 & 51 & 9 & 7 \\
Leaf & 38 & 0 & 38 & 0 & 0 \\
Soil & $\mathrm{NT}$ & $\mathrm{NT}$ & NT & NT & NT \\
2009 & & & & & 54 \\
Flower & 180 & 38 & 41 & 47 & 5 \\
Leaf & 39 & 29 & 2 & 3 & 48 \\
Soil & 81 & 10 & NT & 23 & \\
\hline
\end{tabular}

y Total gram-negative isolates.

${ }^{z}$ Number of isolates with each kasugamycin phenotype. Resistance was defined as low, intermediate, or high based on the growth of isolates on LuriaBertani medium amended with kasugamycin at 100, 250, and $500 \mu \mathrm{g} \mathrm{ml}^{-1}$, respectively; NT $=$ not tested. (available at http://www.sanger.ac.uk/Projects/E_amylovora/). Alignment of the entire $k s g A$ sequence amplified from the original three strains unexposed to kasugamycin revealed $100 \%$ sequence identity (data not shown). $\mathrm{Ks}^{\mathrm{R}}$ mutants Ea1189-2 and Ea273-1 and -2 exhibited identical point mutations at base pair 19 of $k s g A$, which would generate a premature stop codon at amino acid 7 of KsgA (Fig. 3). Mutants Ea273-3, Ea1189-1, and Ea1189-3 exhibited point mutations at base pair 49 and 139, respectively, resulting in mutations that changed the amino acid encoded (G17E and A47S). Ea110-3 had a deletion of a single nucleotide at base pair 126 and Ea110-1 had a 10-nucleotide deletion between base pairs 182 and 193. Both of these deletion events would cause frame shifts resulting in premature stop codons (Fig. 3).

Evaluation of virulence of spontaneous $\mathrm{Ks}^{\mathrm{R}} E$. amylovora strains. The virulence of eight spontaneous $\mathrm{Ks}^{\mathrm{R}}$ E. amylovora mutants with alterations in the $k s g A$ gene was evaluated against their corresponding parental strain using an immature pear assay. Wild-type $\left(\mathrm{Ks}^{\mathrm{S}}\right)$ strain Ea110 caused significantly larger zones of necrosis than $k s g A$ mutant daughter strains Ea110-1 and Ea110-3 at days 5, 6, and 7 after inoculation (Fig. 4A). Wild-type strain Ea273 also exhibited increased virulence compared with $k s g A$ mutant daughter strains Ea273-1, Ea273-2, and Ea273-3 at days 5 and 7 following inoculation (Fig. 4A). Wild-type strain Ea1189 exhibited increased virulence compared with $k s g A$ mutant daughter strains Ea1189-1, Ea1189-2, and Ea1189-3, with significantly larger zones of necrosis observed at day 7 after inoculation (Fig. 4A). We also evaluated bacterial fitness during pathogenesis by measuring cell growth in immature pear tissue during the first 3 days after inoculation. During this time period, the population

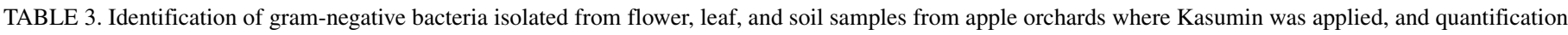
of number of isolates by kasugamycin sensitivity level ${ }^{\mathrm{w}}$

\begin{tabular}{|c|c|c|c|c|c|c|c|c|c|}
\hline \multirow[b]{3}{*}{ Bacterial genus, species ${ }^{\mathrm{x}}$} & \multirow[b]{3}{*}{ Total $^{\mathrm{y}}$} & \multicolumn{8}{|c|}{ No. of isolates capable of growth on medium amended with kasugamycin $\left(\mu \mathrm{g} \mathrm{ml}^{-1}\right)^{\mathrm{z}}$} \\
\hline & & \multicolumn{4}{|c|}{ Flower and leaf } & \multicolumn{4}{|c|}{ Soil } \\
\hline & & $\mathrm{S}$ & 100 & 250 & 500 & $\mathrm{~S}$ & 100 & 250 & 500 \\
\hline \multicolumn{10}{|l|}{ Enterobacteriaceae } \\
\hline Dickeya dadantii & 3 & 2 & 0 & 1 & 0 & 0 & 0 & 0 & 0 \\
\hline Enterobacter sp. & 14 & 1 & 0 & 1 & 0 & 10 & 0 & 0 & 2 \\
\hline Erwinia amylovora & 6 & 5 & 0 & 0 & 0 & 1 & 0 & 0 & 0 \\
\hline E. persicina & 4 & 0 & 4 & 0 & 0 & 0 & 0 & 0 & 0 \\
\hline Klebsiella sp. & 1 & 0 & 0 & 0 & 0 & 1 & 0 & 0 & 0 \\
\hline Pantoea agglomerans & 61 & 24 & 31 & 0 & 2 & 2 & 0 & 2 & 0 \\
\hline Pantoea sp. & 7 & 1 & 2 & 0 & 0 & 2 & 0 & 2 & 0 \\
\hline Serratia sp. & 4 & 0 & 0 & 0 & 0 & 1 & 0 & 0 & 3 \\
\hline Yersinia aldovae & 3 & 1 & 2 & 0 & 0 & 0 & 0 & 0 & 0 \\
\hline Total & 103 & 34 & 39 & 2 & 2 & 17 & 0 & 4 & 5 \\
\hline \multicolumn{10}{|l|}{ Other bacteria } \\
\hline Chryseobacterium sp. & 22 & 0 & 0 & 1 & 3 & 0 & 0 & 0 & 18 \\
\hline Pseudomonas aeruginosa & 6 & 1 & 2 & 1 & 1 & 0 & 0 & 0 & 1 \\
\hline P. fluorescens & 46 & 2 & 5 & 25 & 10 & 0 & 0 & 1 & 3 \\
\hline P. geniculata & 12 & 0 & 1 & 0 & 11 & 0 & 0 & 0 & 0 \\
\hline P. graminis & 58 & 20 & 35 & 0 & 2 & 0 & 0 & 1 & 0 \\
\hline P. putida & 14 & 0 & 9 & 1 & 2 & 0 & 0 & 2 & 0 \\
\hline P. syringae & 26 & 23 & 2 & 0 & 1 & 0 & 0 & 0 & 0 \\
\hline Pseudomonas spp. & 90 & 31 & 17 & 15 & 7 & 5 & 0 & 7 & 8 \\
\hline Sphingomonas sp. & 16 & 0 & 6 & 4 & 1 & 2 & 0 & 1 & 2 \\
\hline Stenotrophomonas maltophilia & 57 & 1 & 0 & 2 & 22 & 2 & 0 & 3 & 27 \\
\hline Stenotrophomonas spp. & 19 & 0 & 5 & 1 & 3 & 1 & 0 & 0 & 9 \\
\hline Xanthomonas campestris & 6 & 0 & 0 & 3 & 2 & 0 & 0 & 0 & 1 \\
\hline Miscellaneous & 113 & 5 & 14 & 6 & 4 & 43 & 0 & 12 & 29 \\
\hline Total & 485 & 83 & 96 & 59 & 69 & 53 & 0 & 27 & 98 \\
\hline
\end{tabular}

${ }^{\mathrm{w}}$ Bacterial isolations were done in 2007, 2008, and 2009.

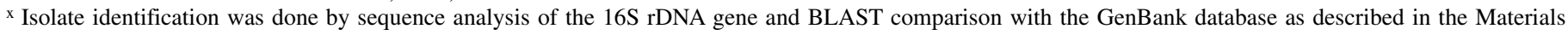
and Methods. Pseudomonas spp. includes Pseudomonas cedrina, P. gingeri, P. lutea, P. rhodesiae, P. poea, P. veronii, P. viridiflava, and Pseudomonas sp. Stentrophomonas spp. includes Stentrophomonas chelatiphaga, S. rhizophila, and Stentrophomonas sp. Miscellaneous bacterial species includes Acinetobacter sp., Aeromonas sp., Agrobacterium tumefaciens, Burkholderia sp., Caulobacter sp., Delftia lacustris, Duganella sp., Ensifer sp., Flavobacterium sp., Pedobacter sp., Psychrobacter sp., Rahnella aquatilis, Rhizobium sp., Variovorax ginsengisoli, and V. paradoxus.

$\mathrm{y}$ Total number of isolates.

${ }^{\mathrm{z}}$ Number of isolates capable of growth on Luria-Bertani medium amended with kasugamycin; $\mathrm{S}=$ sensitive. 
size of wild-type strains appeared to be mostly similar to that of the mutant strains (Fig. 4B), suggesting that any difference in growth that might correspond with differences in virulence would have been observed later during the infection process.

In vitro relative fitness was also evaluated by comparing growth rate and lag time of wild-type and mutant strains in both rich medium (LB) and MM. Growth curves of each of these strains and their corresponding $k s g A$ mutant daughter strains in LB is shown (Fig. 5; data not shown for MM experiments). The mean lag time of strain Ea110 was $3.6 \mathrm{~h}$, which was significantly shorter that that of the corresponding mutant strains Ea110-1 (4.1 h, $P=0.01)$ and Ea110-3 (4.8 h, $P=0.0002)$. The mean doubling time of Ea110 was $1.8 \mathrm{~h}$, which was significantly faster than that of Ea110-1 (2.4 h, $P=0.01)$ and Ea110-3 (2.5 h, $P=$ 0.01 ) (Fig. 5). The mean lag time of Ea1189 of $3.5 \mathrm{~h}$ was significantly shorter than that of two mutants (Ea1189-1, $4.2 \mathrm{~h}$, $P=0.03$ and Ea1189-2, $4.7 \mathrm{~h}, P=0.05)$ and not significantly different from Ea1189-3 (4.4 h, $P=0.14)$. In addition, the mean doubling time of Ea1189 of $2.1 \mathrm{~h}$ was not significantly different from that of any of the corresponding mutant strains (Ea1189-1, $2.1 \mathrm{~h}, P=0.9$; Ea1189-2, $2.5 \mathrm{~h}, P=0.14$; and Ea1189-3, $2.7 \mathrm{~h}$, $P=0.11$ ). The mean lag time of Ea273 was $3.2 \mathrm{~h}$, which was significantly shorter than that of the corresponding mutant strains (Ea273-1, $5.4 \mathrm{~h}, P=0.002$; Ea273-2, $5.0 \mathrm{~h}, P=0.001$; and Ea273-3, $4.1 \mathrm{~h}, P=0.01)$. Likewise, the mean doubling time of Ea273 of $1.6 \mathrm{~h}$ was also significantly reduced compared with the mutant strains (Ea273-1, $2.4 \mathrm{~h}, P=0.005$; Ea273-2, $2.4 \mathrm{~h}, P=$ 0.008; and Ea273-3, $2.0 \mathrm{~h}, P=0.05)$.

Differential sensitivity of bacteria to kasugamycin and Kasumin. The isolate test panel for comparative sensitivity analysis was weighted in favor of the predominant species observed in the distribution of environmental isolates recovered, and in the selection of bacteria commonly isolated from aerial plant tissue. We also tested a collection of 20 strains of E. amylovora, E. pyrifoliae, and Erwinia sp. representing a wide geographic distribution. All 55 environmental isolates from the test panel grew on $\mathrm{KB}$ and $\mathrm{KB}+$ kasugamycin $\left(100 \mu \mathrm{g} \mathrm{m}^{-1}\right)$ but only 16 isolates could grow on $\mathrm{KB}+$ Kasumin with Kasumin included at the same rate of $100 \mu \mathrm{g} \mathrm{ml}^{-1}$ (Table 5). Because of the disparity in growth on the kasugamycin and Kasumin-amended media, we also examined isolate growth on $\mathrm{KB}$ containing the equivalent amount of the KFB. Only 36 of 55 isolates from the test panel grew on KB amended with the KFB, indicating that the KFB had some antimicrobial activity (Table 5 ). When we added a corresponding amount of the formulation blank to $\mathrm{KB}$ medium containing technical-grade kasugamycin at $100 \mu \mathrm{g} \mathrm{ml}^{-1}$, the number of isolates capable of growth was reduced from 55 to 36 . We also found that, whereas 11 of the Stenotrophomonas spp. examined grew on KBks + blank medium, only 3 of these isolates grew on $\mathrm{KB}+\mathrm{KFB}$ without antibiotic added (Table 5). All of the $E$. amylovora, E. pyrifoliae, and Erwinia sp. strains examined could grow on KFB but none of these strains could grow on $\mathrm{KB}$ amended with kasugamycin or Kasumin (Table 5). In addition, the 18 E. amylovora strains tested included nine $\mathrm{Sm}^{\mathrm{R}}$ strains; none of these strains could grow on KBks.

\section{DISCUSSION}

Our field experiments indicated that Kasumin significantly reduced blossom infection by E. amylovora when applied both before and after pathogen inoculation and when applied only after pathogen inoculation. The efficacy of Kasumin was not significantly different from that of Agri-Mycin, which was the standard material used for blossom blight control prior to the development of streptomycin resistance. The effect of Kasumin on reduction of E. amylovora populations on apple flower stigmas was also similar to that of streptomycin. In field studies conducted by other researchers, the efficacy of Kasumin for blossom blight control was also equal to that of Agri-Mycin $(1,18)$. Taken together, all of these results indicate that Kasumin represents a viable alternative antibiotic, in particular for use for fire blight management in orchards harboring $\mathrm{Sm}^{\mathrm{R}}$ strains of E. amylovora.

The long-term utility of kasugamycin for fire blight control is dependent upon the development of resistance in the pathogen population. Loss of kasugamycin efficacy to resistance in $E$. amylovora is predicted to occur through either of two mechanisms. The first possibility would involve the development and selection of spontaneous $\mathrm{Ks}^{\mathrm{R}}$ mutants. In our laboratory studies, direct exposure of three different E. amylovora strains to high concentrations of kasugamycin did not result in the recovery of spontaneous $\mathrm{Ks}^{\mathrm{R}}$ colonies. However, exposure of E. amylovora initially to low concentrations of kasugamycin followed by progressive increases in concentration of kasugamycin from 25 to $200 \mu \mathrm{g} \mathrm{ml}^{-1}$ did result in the recovery of strains that could grow in

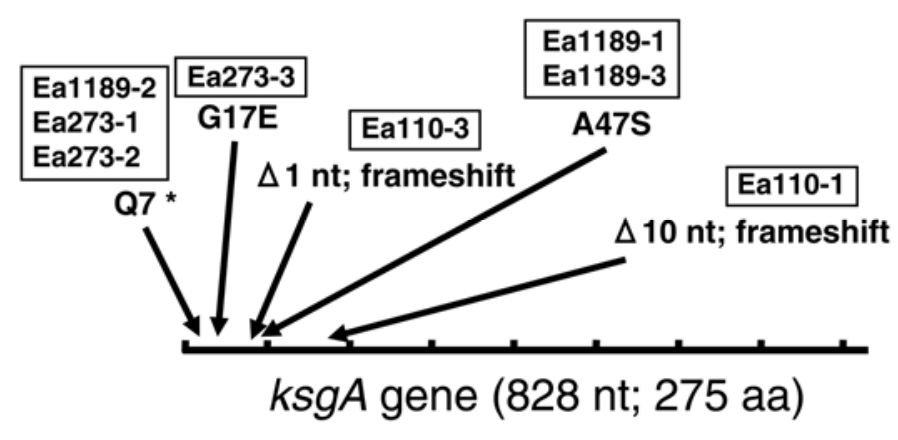

Fig. 3. Graphic representation of the $k s g A$ gene from Erwinia amylovora indicating the location of mutations in eight spontaneous kasugamycinresistant mutants of E. amylovora strains Ea110, Ea273, and Ea1189 and the corresponding amino acid change in the translated protein or frameshift.

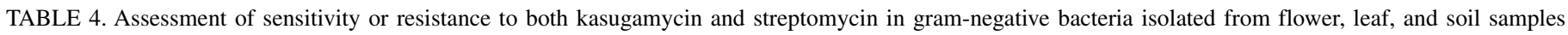
from apple orchards where Kasumin was applied

\begin{tabular}{|c|c|c|c|c|c|}
\hline \multirow[b]{2}{*}{ Bacterial group (family or genus) } & \multirow[b]{2}{*}{ Total no. of isolates } & \multicolumn{4}{|c|}{ No. of isolates with each kasugamycin and streptomycin resistance phenotype ${ }^{z}$} \\
\hline & & $\mathrm{Ks}^{\mathrm{S}} \mathrm{Sm}^{\mathrm{S}}$ & $\mathrm{Ks}^{\mathrm{S}} \mathrm{Sm}^{\mathrm{R}}$ & $\mathrm{Ks}^{\mathrm{R}} \mathrm{Sm}^{\mathrm{S}}$ & $\mathrm{Ks}^{\mathrm{R}} \mathrm{Sm}^{\mathrm{R}}$ \\
\hline \multicolumn{6}{|l|}{ Flower and leaf } \\
\hline Enterobacteriaceae & 77 & 16 & 17 & 4 & 40 \\
\hline Pseudomonas spp. & 224 & 13 & 68 & 14 & 129 \\
\hline Stentrophomonas spp. & 34 & 1 & 0 & 6 & 27 \\
\hline Other gram-negative bacteria & 49 & 1 & 4 & 16 & 28 \\
\hline \multicolumn{6}{|l|}{ Soil } \\
\hline Enterobacteriaceae & 26 & 4 & 13 & 4 & 5 \\
\hline Pseudomonas spp. & 28 & 1 & 4 & 17 & 6 \\
\hline Stentrophomonas spp. & 42 & 3 & 0 & 21 & 18 \\
\hline Other gram-negative bacteria & 108 & 23 & 22 & 28 & 35 \\
\hline
\end{tabular}

${ }^{\mathrm{z}} \mathrm{Ks}^{\mathrm{S}}$ and $\mathrm{Sm}^{\mathrm{S}}=$ sensitive and $\mathrm{Ks}^{\mathrm{R}}$ and $\mathrm{Sm}^{\mathrm{R}}=$ resistant to kasugamycin and streptomycin, respectively. 


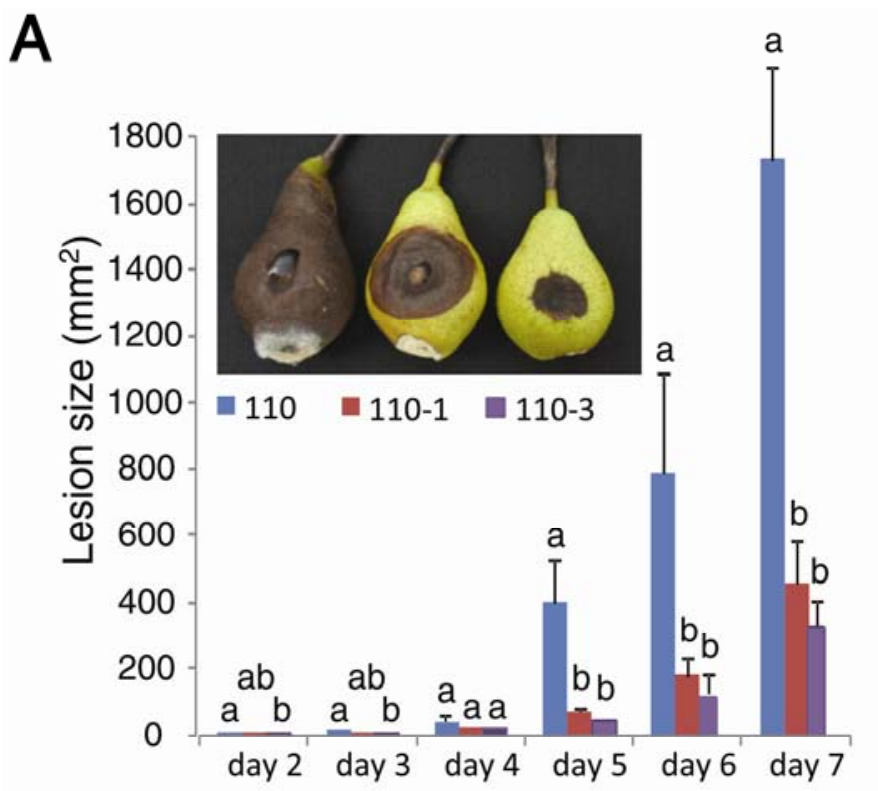

B
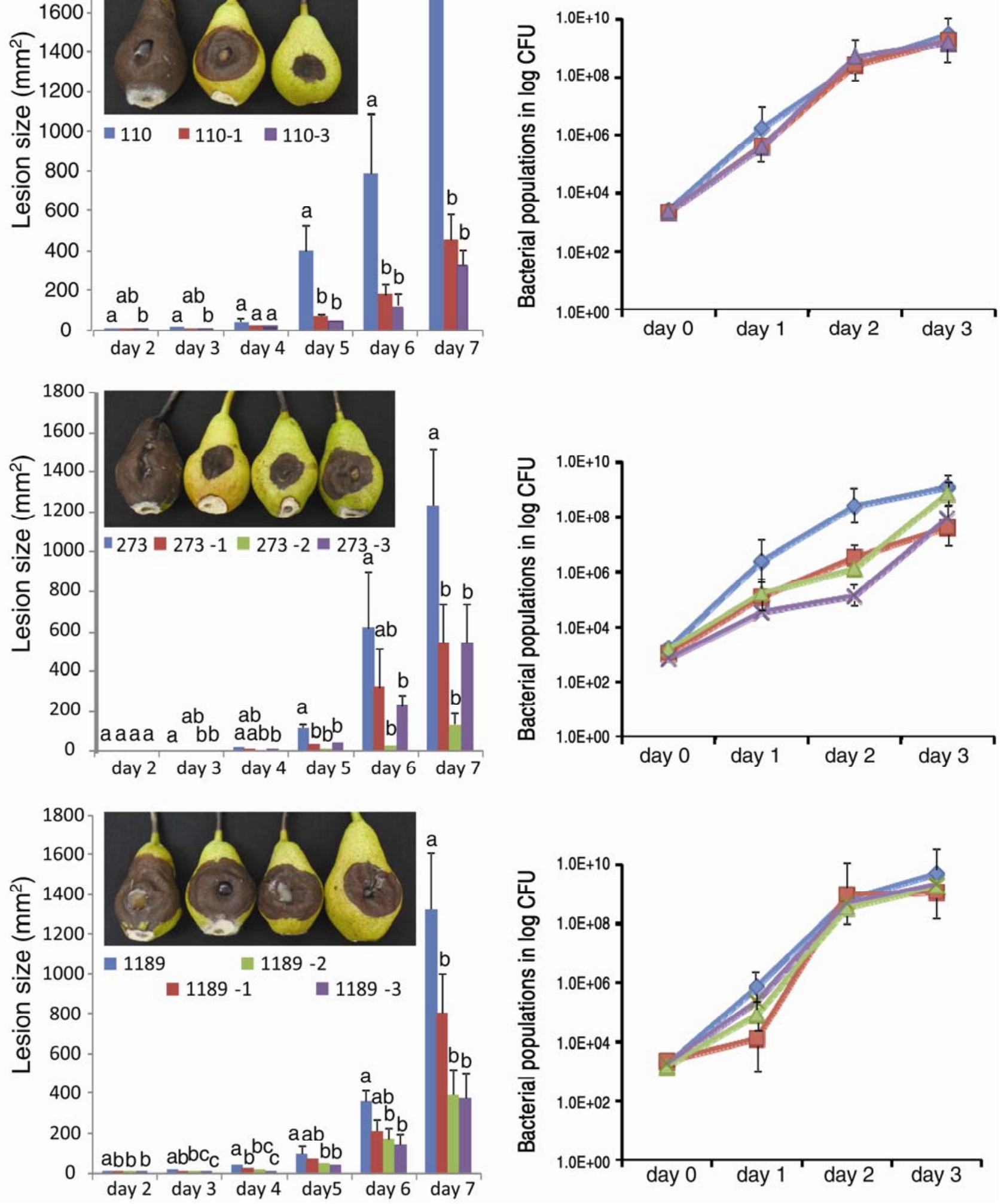

Fig. 4. Virulence assays in immature pear fruit performed with wild-type and eight spontaneous kasugamycin-resistant mutants of Erwinia amylovora strains Ea110, Ea273, and Ea1189. A, Necrotic lesion size (with standard error) in immature pear following inoculation with E. amylovora strains. Data pooled from two experiments are shown. The presence of different small letters above the bars indicates that the means within a treatment are significantly different $(P<0.05)$ according to Fisher's protected least significant difference test. These experiments were performed over 7 days with measurements taken at days $2,3,4,5,6$, and 7. In all, 10 immature pear fruit were used for each strain in each experiment. Representative pear fruit inoculated with wild-type and mutant strains from day 7 are shown in the inset. The key indicates the color of the bars representing data from a particular strain. B, Population size of wild-type and mutant strains (and standard error) immediately following inoculation and over a 3-day period following inoculation into immature pear fruit. 
the presence of kasugamycin at a concentration of at least $150 \mu \mathrm{g}$ $\mathrm{ml}^{-1}$. Furthermore, these bacteria exhibited heritable alterations in the $k s g A$ gene that were presumably associated with decreased sensitivity. It is possible that populations of E. amylovora could be exposed to relatively lower concentrations of kasugamycin in orchards due to either inadequate spray coverage or environmental degradation of kasugamycin. However, the stability of the $k s g A$ mutations and the relative fitness of spontaneous $\mathrm{Ks}^{\mathrm{R}}$ strains would also play a role in the maintenance of such strains in orchard populations. Our results with the spontaneous $\mathrm{Ks}^{\mathrm{R}}$ mutants selected in this study indicated that these strains were reduced in virulence in an immature pear assay. Although this result suggests that spontaneous $\mathrm{Ks}^{\mathrm{R}}$ mutants would be reduced in fitness, these mutants would have to be further evaluated because it is known that spontaneous antibiotic-resistant bacterial mutants can evolve compensatory mutations that alleviate fitness defects (3).

A second potential method for the development of resistance to kasugamycin in E. amylovora orchard populations would be through the acquisition of a kasugamycin resistance gene by horizontal DNA transfer. Although there are currently no known transferrable kasugamycin resistance genes in bacteria, it is likely that such genes exist in nature because kasugamycin is a natural product of the bacterium Streptomyces kasugaensis in soil environments (16), suggesting that kasugamycin selection would theoretically be present in soil microbial communities. We isolated a wide range of $\mathrm{Ks}^{\mathrm{R}}$ gram-negative bacteria from apple flowers and leaves and orchard soil in this study. Two ecological factors that could affect the transfer of a kasugamycin resistance gene, if present in the orchard microbial community, into $E$. amylovora would be the location of the gene in an organism that could attain relatively large population sizes in the apple flower and leaf habitat and the possible presence of a transferrable gene in an organism relatively closely related to E. amylovora. Of the $\mathrm{Ks}^{\mathrm{R}}$ bacterial species and genera identified in this study, most were known residents of the plant phyllosphere or known colonists of apple such as Pantoea agglomerans, Pseudomonas graminis, P. syringae, and Stenotrophomonas spp. $(4,13,15,17)$. Thus, it would be expected that, if these organisms carried a mobile kasugamycin resistance gene, they could reach sufficient population size on apple tissue to effect gene transfer to $E$. amylovora, potentially via conjugation.

We also determined that $72.4 \%$ of the $\mathrm{Ks}^{\mathrm{R}}$ bacteria recovered (288 of 398 isolates) were also resistant to streptomycin. The occurrence of the $\mathrm{Ks}^{\mathrm{R}} \mathrm{Sm}^{\mathrm{R}}$ phenotype in Enterobacteriaceae isolates and Pseudomonas spp. is of concern because these organisms could potentially be involved in the dissemination of resistance genes to E. amylovora. The high percentage of $\mathrm{Sm}^{\mathrm{R}}$ bacteria recovered was not surprising because streptomycin has been applied yearly in the orchard where we sampled for fire blight control for at least 25 years. It has been shown in studies involving different crop hosts that the use of streptomycin as a bactericide for plant disease control selects for streptomycin resistance in nontarget commensal bacteria that inhabit either plant surfaces or the surrounding soil $(7,48)$. The isolation of a number of bacteria with resistance to both kasugamycin and streptomycin may be indicative of the selection of kasugamycin resistance in strains already harboring streptomycin resistance or may be due to the presence of bacteria that are intrinsically resistant to both of these aminoglycoside antibiotics. Because we found that spontaneous $\mathrm{Ks}^{\mathrm{R}}$ E. amylovora strains were sensitive to streptomycin and that spontaneous $\mathrm{Sm}^{\mathrm{R}}$ E. amylovora strains were sensitive to kasugamycin, there is no concern for cross resistance among singly resistant $\mathrm{Ks}^{\mathrm{R}}$ or $\mathrm{Sm}^{\mathrm{R}}$ spontaneous mutants. This will become important if Kasumin is utilized as a resistance management tool in situations where the E. amylovora background population is still sensitive to streptomycin.

In addition, we isolated a number of enterobacterial species from apple flowers and leaves; of these, Pantoea agglomerans was the most prevalent. This is significant because P. agglomerans was thought to be the source of the streptomycin-resistance plasmid $\mathrm{pEa} 34$, which was acquired by E. amylovora in Michigan (7). Transferrable streptomycin resistance in E. amylovora and other plant pathogens, including Pseudomonas syringae, is conferred by the linked $\operatorname{str} A-s t r B$ genes which are encoded within
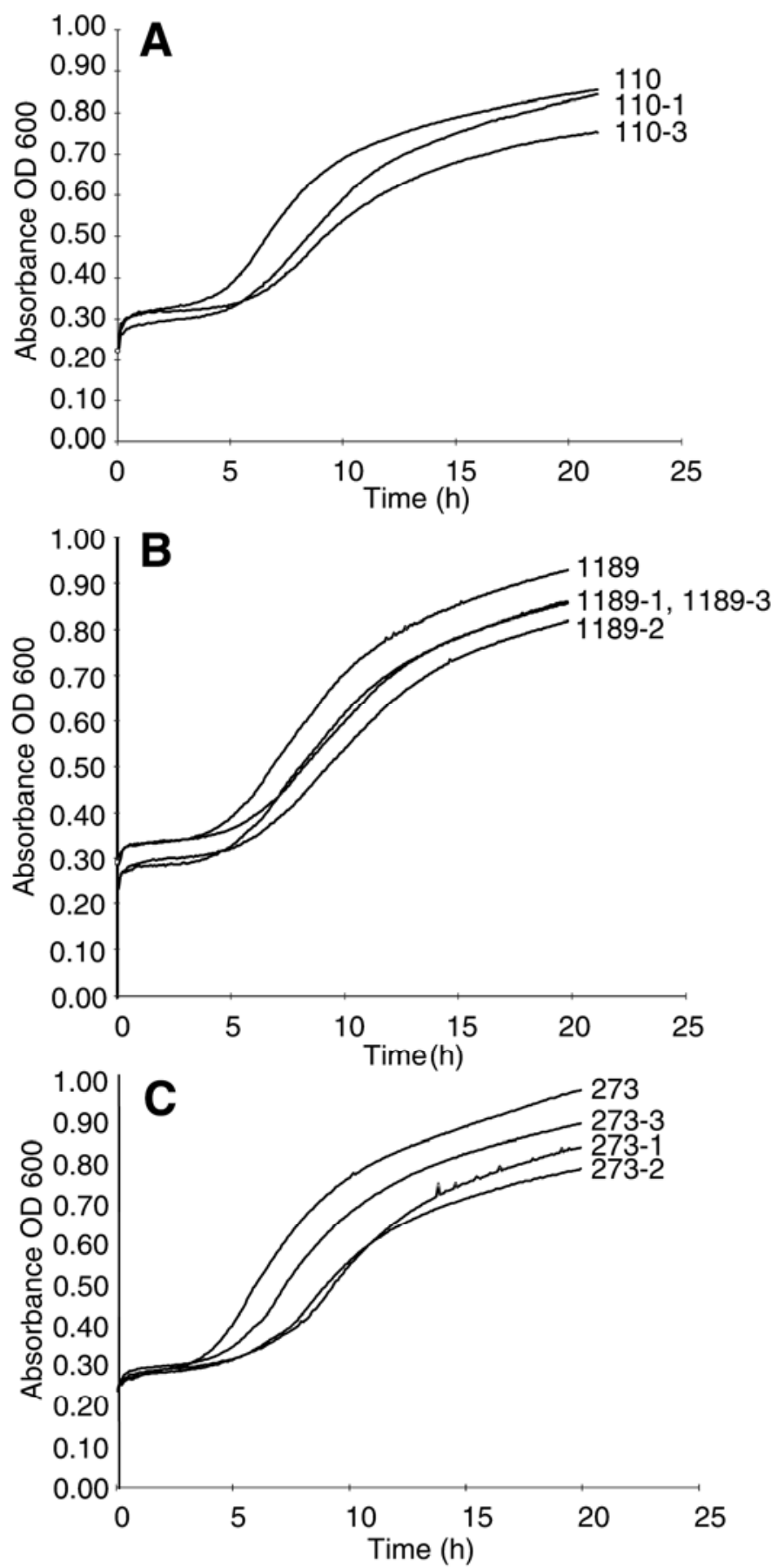

Fig. 5. Growth curves of wild-type and eight spontaneous kasugamycinresistant mutants of Erwinia amylovora A, Ea110; B, Ea1189; and C, Ea273 in Luria-Bertani (LB) broth. Strains indicated with dashes (e.g., Ea110-1) are the corresponding spontaneous kasugamycin-resistant mutant strains. Diluted bacterial suspension $(2 \mathrm{ml})$ in media was inoculated into three replicate wells of a 24-well microtiter plate and sealed. Optical density (OD) readings $(600 \mathrm{~nm})$ were taken every $5 \mathrm{~min}$ using a Tecan Safire plate reader for $24 \mathrm{~h}$. The microtiter plates were shaken for $30 \mathrm{~s}$ at $2.5 \mathrm{~min}$ between readings and just prior to each optical read. Bacteria were allowed to settle for $10 \mathrm{~s}$ prior to reading. Representative curves for each organism were chosen and graphed as a function of absorbance over time in hours. The experiment was replicated twice in both LB and minimal media (data not shown). 
the transposable element Tn5393 $(7,44,45)$. The $s t r A-s t r B$ genes and the Tn5393 element are also present in nontarget bacteria isolated from the same orchard and nursery environments as the pathogens $(7,48)$, suggesting the likelihood that nontarget bacteria served as the donors of streptomycin resistance to the plant pathogens.

We must stress that, although large numbers of $\mathrm{Ks}^{\mathrm{R}}$ organisms from diverse species were isolated in this study, it is currently unknown if any of these $\mathrm{Ks}^{\mathrm{R}}$ nontarget bacteria isolated harbor a transferrable kasugamycin resistance gene. However, it is clear that the possibility already exists that bacteria harboring a transferrable kasugamycin resistance gene could be readily selected in orchards where Kasumin is applied for fire blight disease management. It is also possible that some of the $\mathrm{Ks}^{\mathrm{R}}$ nontarget bacteria that were isolated are intrinsically resistant to kasugamycin through mechanisms such as reduced antibiotic uptake or enhanced efflux. For example, it is known that Stenotrophomonas maltophilia exhibits intrinsic resistance to aminoglycoside antibiotics such as kasugamycin (22), and a number of isolates of this organism exhibiting high-level kasugamycin resistance were recovered in this study. Thus, a critical next step for this research is to determine whether any transferrable kasugamycin resistance genes are present in the bacterial communities of Kasumin-sprayed orchards.

Antibiotic resistance is a global problem with severe consequences in clinical medicine (2). From a scientific perspective, the emergence of antibiotic resistance in clinical bacteria is explained by several broad concepts: (i) most antibiotics are produced naturally by environmental bacteria, and resistance genes originally evolved long ago in response to natural antibiotic selection; (ii) antibiotic resistance genes are typically associated with mobile genetic elements; (iii) in clinical situations, mobile antibiotic resistance genes are usually acquired first by nontarget commensal organisms and then transferred to pathogens; (iv) the combination of the large size of bacterial populations, selection pressure imposed by large-scale human use of antibiotics, and transferrable resistance genes has resulted in the current situation, in which similar antibiotic resistance genes are widely disseminated among a variety of unrelated bacterial pathogens (11).

Because antibiotic resistance genes are so easily transferred among bacteria, even among unrelated species, there are concerns in the medical community regarding the potential for the transfer of resistance genes selected in agricultural habitats to human pathogens. These concerns are valid in the animal agriculture arena, with an example being the selection of clinically important vancomycin-resistant enterococci initially in chickens given the antibiotic avoparcin as a feed additive for growth promotion (56). The current use of the antibiotic gentamicin for bacterial disease control on plants in Mexico and other Central American countries has heightened these concerns, in particular, because of the use of gentamicin in clinical medicine. However, although gentamicin resistance is a problem in clinical medicine, gentamicin resistance genes are also already commonly found in habitats associated with or impacted by sewage effluent or farm animals (14). Thus, the possibility for transfer of gentamicin resistance from environmental sources to human-associated bacteria already exists and the number of these currently existing environmental sources would be expected to be orders of magnitude greater than the number of sources from plant agriculture.

It should also be noted that current antibiotic use in plant agriculture in the United States (streptomycin and oxytetracycline) represents $<0.5 \%$ of the total agricultural antibiotic use $(32,54)$. The availability of rapid sequencing technologies has aided in the identification of specific resistance genes and alleles in plant-pathogenic bacteria and in the determination of possible relationships with similar genes found in clinical bacteria. For example, the strA-strB streptomycin resistance genes found in plant-pathogenic bacteria are also widely distributed in clinical pathogens (47); however, the alleles of the genes were different, suggesting different routes of acquisition $(44,45)$. Thus, the detection of similar antibiotic resistance genes in plant-associated bacteria and clinical pathogens does not necessarily signify direct horizontal transfer events between organisms from these disparate habitats.

Kasugamycin is an attractive antibiotic for the management of bacterial plant pathogens because there are no uses of this antibiotic in human medicine. In addition, there are no known kasugamycin resistance genes currently, although spontaneous $\mathrm{Ks}^{\mathrm{R}}$ mutants of E. amylovora were selected in this study and have been genetically characterized in Escherichia coli (55). Our observations on the lack of sensitivity to kasugamycin of many nontarget bacteria inhabiting apple orchards could also reduce the risk potential for resistance development in E. amylovora. Because many bacteria capable of growth in the presence of kasugamycin at $100 \mu \mathrm{g} \mathrm{ml}^{-1}$ were isolated from orchards, it is possible that applications of Kasumin for blossom blight control at $100 \mu \mathrm{g} \mathrm{ml}^{-1}$ will not affect these organisms. This would be advantageous if these organisms were intrinsically resistant to kasugamycin. Thus, organisms with intrinsic resistance to kasugamycin would survive spray applications but would not contribute to the selective pressure to obtain and disseminate a potential

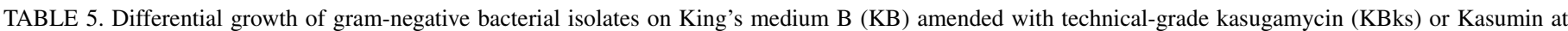
$100 \mu \mathrm{g} \mathrm{ml} \mathrm{m}^{-1}$, the Kasumin formulation blank (KFB), or kasugamycin plus KFB

\begin{tabular}{|c|c|c|c|c|c|c|}
\hline \multirow[b]{2}{*}{ Bacterial species ${ }^{\mathrm{y}}$} & \multirow[b]{2}{*}{ No. ${ }^{\mathrm{z}}$} & \multicolumn{5}{|c|}{ No. of isolates growing on media } \\
\hline & & $\mathrm{KB}$ & $\mathrm{KB}+\mathrm{KFB}$ & $\mathrm{KB}+\mathrm{KBks}\left(100 \mu \mathrm{g} \mathrm{ml}^{-1}\right)$ & $\mathrm{KB}+\operatorname{Kasumin}\left(100 \mu \mathrm{g} \mathrm{ml}^{-1}\right)$ & KBks $\left(100 \mu \mathrm{g} \mathrm{ml}^{-1}\right)+\mathrm{KFB}$ \\
\hline Chryseobacterium sp. & 1 & 1 & 0 & 1 & 0 & 1 \\
\hline Dickeya dadanti & 1 & 1 & 1 & 1 & 0 & 0 \\
\hline Enterobacter sp. & 2 & 2 & 1 & 2 & 1 & 2 \\
\hline Erwinia amylovora & 18 & 18 & 18 & 0 & 0 & 0 \\
\hline E. persicina & 4 & 4 & 0 & 4 & 0 & 4 \\
\hline E. pyrifoliae & 1 & 1 & 1 & 0 & 0 & 0 \\
\hline Erwinia sp. & 1 & 1 & 1 & 0 & 0 & 0 \\
\hline Pantoea agglomerans & 20 & 20 & 20 & 20 & 4 & 9 \\
\hline Pseudomonas sp. & 2 & 2 & 1 & 2 & 1 & 1 \\
\hline Pseudomonas aeruginosa & 4 & 4 & 2 & 4 & 2 & 2 \\
\hline P. fluorescens & 6 & 6 & 6 & 6 & 3 & 4 \\
\hline P. syringae & 2 & 2 & 2 & 2 & 0 & 0 \\
\hline Stenotrophomonas spp. & 13 & 13 & 3 & 13 & 5 & 11 \\
\hline
\end{tabular}

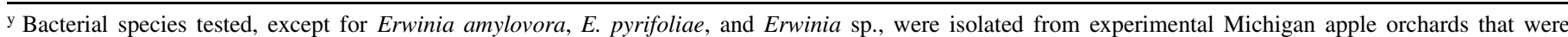
previously treated at least once with Kasumin. The E. amylovora, E. pyrifoliae, and Erwinia sp. strains tested represented a collection of strains isolated from the United States, Asia, Europe, and the Middle East.

z Number of strains tested. 
kasugamycin resistance gene. With less selection pressure for resistance development in nontarget organisms, the potential for introduction of transferrable kasugamycin resistance genes is expected to be low.

The observation that some bacteria were more sensitive to the formulated product Kasumin than to kasugamycin was also interesting and may slow the potential for resistance development in certain bacterial species. The Kasumin formulated product consists of kasugamycin and additional proprietary components (V. J. Spadafora, personal communication). It is possible that these additional ingredients may stabilize the kasugamycin antibiotic in solution or may impact bacterial cell membranes, which could increase the permeability of the antibiotic. However, in some cases, the formulation blank itself had bactericidal activity, which could result via induction of membrane leakage. The increased sensitivity of most of the Pantoea agglomerans strains to Kasumin compared with kasugamycin could also be significant in that a $P$. agglomerans strain was implicated in the transfer of the $\mathrm{Sm}^{\mathrm{R}}$ transposon $\mathrm{Tn} 5393$ into Erwinia amylovora (7).

In summary, we have determined that Kasumin, a formulated bactericide with the antibiotic kasugamycin as active ingredient, is highly efficacious for controlling the blossom blight phase of fire blight and represents a new alternative antibiotic for the management of E. amylovora. The lack of medical uses of kasugamycin significantly increases the attractiveness of this antibiotic for plant agricultural use. We determined that exposure of E. amylovora to low concentrations of kasugamycin heightened the risk of spontaneous resistance development. Thus, it will be critical that full label rates of Kasumin are consistently utilized for control and that spray methodologies such as alternate-row spraying that can reduce the amount of available product on trees should be avoided. We are currently examining a variety of orchard bacterial isolates for the possible presence of transferrable kasugamycin resistance genes. If any genes are identified, we can assess their distribution and potential for horizontal transfer among nontarget organisms and into E. amylovora.

\section{ACKNOWLEDGMENTS}

This work was supported by the Michigan Apple Committee, Michigan Agricultural Experiment Station, Michigan State University Project GREEEN, and a special grant from the United States Department of Agriculture, CSREES. We thank G. Ehret and J. Guasco for valuable technical assistance, M. Weigand for assistance with statistical analyses, R. Schmid for assistance with data management, and J. Spadafora and Arysta LifeScience for donating quantities of Kasumin and the formulation blank utilized in field trials and laboratory analyses.

\section{LITERATURE CITED}

1. Adaskaveg, J. E., Driever, G. F., Forster, H., Gubler, W. D., Wade, L. M., and Holtz, B. 2008. Detection of Erwinia amylovora strains with reduced sensitivity to currently registered antibiotics and management of fire blight of pome fruits using kasugamycin in integrated strategies. Acta Hortic. 793:375-382.

2. Alanis, A. J. 2005. Resistance to antibiotics: are we in the post-antibiotic era? Archiv. Med. Res. 36:697-705.

3. Andersson, D. I., and Hughes, D. 2010. Antibiotic resistance and its cost: is it possible to reverse resistance? Nat. Rev. Microbiol. 8:260-271.

4. Behrendt, U., Ulrich, A., Schumann, P., Erler, W., Burghardt, J., and Seyfarth, W. 1999. A taxonomic study of bacteria isolated from grasses: a proposed new species Pseudomonas graminis sp. nov. Int. J. Syst. Bacteriol. 49:297-308.

5. Berry, M. C., McGhee, G. C., Zhao, Y., and Sundin, G. W. 2009. Effect of a waaL mutation on lipopolysaccharide composition, oxidative stress survival, and virulence in Erwinia amylovora. FEMS Microbiol. Lett. 291:80-87.

6. Chiou, C.-S., and Jones, A. L. 1991. The analysis of plasmid-mediated streptomycin resistance in Erwinia amylovora. Phytopathology 81:710714.

7. Chiou, C.-S., and Jones, A. L. 1993. Nucleotide sequence analysis of a transposon (Tn5393) carrying streptomycin resistance genes in Erwinia amylovora and other gram-negative bacteria. J. Bacteriol. 175:732-740.

8. Clarridge, J. E. 2004. Impact of 16S rRNA gene sequence analysis for identification of bacteria on clinical microbiology and infectious diseases. Clin. Microbiol. Rev. 17:840-862.

9. Copping, L. G., and Duke, S. O. 2007. Natural products that have been used commercially as crop protection agents. Pest Manage. Sci. 63:524554.

10. Coyier, D. L., and Covey, R. P. 1975. Tolerance of Erwinia amylovora to streptomycin sulfate in Oregon and Washington. Plant Dis. Rep. 59:849852.

11. Davies, J. 1994. Inactivation of antibiotics and the dissemination of resistance genes. Science 264:375-382.

12. Foster, G. C., McGhee, G. C., Jones, A. L., and Sundin, G. W. 2004. Nucleotide sequences, genetic organization, and distribution of pEU30 and pEL60 from Erwinia amylovora. Appl. Environ. Microbiol. 70:75397544.

13. Hayward, A. C., Fegan, N., Fegan, M., and Stirling, G. R. 2010. Stenotrophomonas and Lysobacter: ubiquitous plant-associated gammaproteobacteria of developing significance in applied microbiology. J. Appl. Microbiol. 108:756-770.

14. Heuer, H., Krogerrecklenfort, E., Wellington, E. M. H., Egan, S., van Elsas, J. D., van Overbeek, L., Collard, J. M., Guillame, G., Karagouni, A. D., Nikolakopoulou, T. L., and Smalla, K. 2002. Gentamicin resistance genes in environmental bacteria: prevalence and transfer. FEMS Microbiol. Ecol. 42:289-302.

15. Hirano, S. S., and Upper, C. D. 2000. Bacteria in the leaf ecosystem with emphasis on Pseudomonas syringae: a pathogen, ice nucleus, and epiphyte. Microbiol. Mol. Biol. Rev. 64:624-653.

16. Jo, Y. Y., Liu, J., Jin, Y. Y., Yang, Y. Y., and Suh, J. W. 2005. Isolation and characterization of kasugamycin biosynthetic genes from Streptomyces kasugaensis KACC 20262. J. Microbiol. Biotechnol. 15:491-496.

17. Johnson, K. B., Stockwell, V. O., Sawyer, T. L., and Sugar, D. 2000. Assessment of environmental factors influencing growth and spread of Pantoea agglomerans on and among blossoms of pear and apple. Phytopathology 90:1285-1294.

18. Johnson, K. B., Stockwell, V. O., and Temple, T. N. 2008. Evaluation of kasugamycin as a component of an integrated biological and chemical strategy for suppression of blossom blight. Acta Hortic. 793:439-444.

19. Kumar, K., Gupta, S. C., Chander, Y., and Singh, A. K. 2005. Antibiotic use in agriculture and its impact on the terrestrial environment. Adv. Agron. 87:1-54.

20. Lenski, R. E., Souza, V., Duong, L. P., Nguyen, T. N. M., and Bertrand, K. P. 1994. Epistatic effects of promoter and repressor functions of the $\operatorname{Tn} 10$ tetracycline-resistance operon on the fitness of Escherichia coli. Mol. Ecol. 3:127-135

21. Levy, S. B., and Marshall, B. 2004. Antibacterial resistance worldwide: causes, challenges and responses. Nat. Med. 10:S122-S129.

22. Looney, W. J., Narita, M., and Muhlemann, K. 2009. Stenotrophomonas maltophilia: an emerging opportunist human pathogen. Lancet Infect. Dis. 9:312-323.

23. Loper, J. E., Henkels, M. D., Roberts, R. G., Grove, G. G., Willett, M. J., and Smith, T. J. 1991. Evaluation of streptomycin, oxytetracycline, and copper resistance in Erwinia amylovora isolated from pear orchards in Washington state. Plant Dis. 75:287-290.

24. King, E. O., Ward, N. K., and Raney, D. E. 1954. Two simple media for the demonstration of pyocyanin and fluorescein. J. Lab. Clin. Med. 44:301-307.

25. Madigan, M. T., and Martinko, J. M. 2006. Brock Biology of Microorganisms, 11th ed. Pearson Prentice Hall, Upper Saddle River, NJ.

26. Manulis, S., Zutra, D., Kleitman, F., Drox, O., David, I., Zilberstaine, M., and Shabi, E. 1998. Distribution of streptomycin-resistant strains of Erwinia amylovora in Israel and occurrence of blossom blight in the autumn. Phytoparasitica 26:223-230.

27. Marchesi, J. R., Sato, T., Weightman, A. J., Fry, J. C., Hiom, S. J., and Wade, W. G. 1998. Design and evaluation of useful bacterium-specific PCR primers that amplify genes coding for bacterial 16S rRNA. Appl. Environ. Microbiol. 64:795-799.

28. Maxson-Stein, K., McGhee, G. C., Smith, J. J., Jones, A. L., and Sundin, G. W. 2003. Genetic analysis of a pathogenic Erwinia sp. isolated from pear in Japan. Phytopathology 93:1393-1399.

29. McGhee, G. C., Guasco, J., Bellomo, L. M., Blumer-Schuette, S. E., Shane, W. W., Irish-Brown, A., and Sundin, G. W. 2011. Genetic analysis of streptomycin-resistant $\left(\mathrm{Sm}^{\mathrm{R}}\right)$ strains of Erwinia amylovora suggests that dissemination of two genotypes is responsible for the current distribution of $\mathrm{Sm}^{\mathrm{R}}$ E. amylovora in Michigan. Phytopathology 101;182191.

30. McGhee, G. C., and Jones, A. L. 2000. Complete nucleotide sequence of ubiquitous plasmid pEA29 from Erwinia amylovora strain Ea88: Gene organization and intraspecies variation. Appl. Environ. Microbiol. 66:4897-4907. 
31. McManus, P. S., and Jones, A. L. 1994. Epidemiology and genetic analysis of streptomycin resistant Erwinia amylovora and evaluation of oxytetracycline for control. Phytopathology 84:627-633.

32. McManus, P. S., Stockwell, V. O., Sundin, G. W., and Jones, A. L. 2002. Antibiotic use in plant agriculture. Annu. Rev. Phytopathol. 40:443-465.

33. Norelli, J. L., Jones, A. L., and Aldwinckle, H. S. 2003. Fire blight management in the twenty-first century: Using new technologies that enhance host resistance in apple. Plant Dis. 87:756-765.

34. Psallidas, P. G., and Tsiantos, J. 2000. Chemical control of fire blight. Pages 199-234 in: Fire blight: the disease and its causative agent, Erwinia amylovora. J. L. Vanneste, ed. CABI Publishing, Wallingford, Oxon, UK.

35. Pusey, P. L. 1997. Crab apple blossoms as a model for research on biological control of fire blight. Phytopathology 87:1096-1102.

36. Pusey, P. L. 2000. The role of water in epiphytic colonization and infection of pomaceous flowers by Erwinia amylovora. Phytopathology 90:1352-1357.

37. Pusey, P. L. 2002. Biological control agents for fire blight of apple compared under conditions limiting natural dispersal. Plant Dis. 86:639-644.

38. Russo, N. L., Burr, T. J., Breth, D. I., and Aldwinckle, H. S. 2008. Isolation of streptomycin-resistant isolates of Erwinia amylovora in New York. Plant Dis. 92:714-718.

39. Schaad, N. W., Jones, J. B., and Chun, W., eds. 2001. Laboratory Guide for the Identification of Plant Pathogenic Bacteria, 3rd ed. American Phytopathological Society Press, St. Paul, MN.

40. Schroth, M. N., Thomson, S. V., and Moller, W. J. 1979. Streptomycin resistance in Erwinia amylovora. Phytopathology 69:565-568.

41. Sholberg, P. L., Bedford, K. E., Haag, P., and Randall, P. 2001. Survey of Erwinia amylovora isolates from British Columbia for resistance to bactericides and virulence on apple. Can. J. Plant Pathol. 23:60-67.

42. Shwartz, H., Shtienberg, D., Vintal, H., and Kritzman, G. 2003. The interacting effects of temperature, duration of wetness and inoculum size on the infection of pear blossoms by Erwinia amylovora, the causal agent of fire blight. Phytoparasitica 31:174-187.

43. Smith, D. L., Dushoff, J., and Morris, G. 2005. Agricultural antibiotics and human health: Does antibiotic use in agriculture have a greater impact than hospital use? Plos Med. 2:e232.

44. Sundin, G. W. 2000. Examination of base pair variants of the strA-strB streptomycin resistance genes from bacterial pathogens of humans, animals, and plants. J. Antimicrobl. Chemother. 48:848-849.

45. Sundin, G. W. 2002. Distinct recent lineages of the $\operatorname{str} A-\operatorname{str} B$ strepto- mycin-resistance genes in clinical and environmental bacteria. Curr. Microbiol. 45:63-69.

46. Sundin, G. W., and Bender, C. L. 1995. Expression of the $\operatorname{str} A-\operatorname{str} B$ streptomycin resistance genes in Pseudomonas syringae and Xanthomonas campestris and characterization of IS6100 in X. campestris. Appl. Environ. Microbiol. 61:2891-2897.

47. Sundin, G. W., and Bender, C. L. 1996. Dissemination of the $\operatorname{strA}-\operatorname{str} B$ streptomycin-resistance genes among commensal and pathogenic bacteria from humans, animals and plants. Mol. Ecol. 5:133-143.

48. Sundin, G. W., Monks, D. E., and Bender, C. L. 1995. Distribution of the streptomycin-resistance transposon Tn5393 among phylloplane and soil bacteria from managed agricultural habitats. Can. J. Microbiol. 41:792799.

49. Sundin, G. W., Werner, N. A., Yoder, K. S., and Aldwinckle, H. S. 2009. Field evaluation of biological control of fire blight in the eastern United States. Plant Dis. 93:386-394.

50. Taylor, R. K., Hale, C. N., Henshall, W. R., Armstrong, J. L., and Marshall, J. W. 2003. Effect of inoculum dose on infection of apple (Malus domestica) flowers by Erwinia amylovora. N. Z. J. Crop Hortic. Sci. 31:325-333.

51. Thomson, S. V., and Gouk, S. C. 2003. Influence of age of apple flowers on growth of Erwinia amylovora and biological control agents. Plant Dis. 87:502-509.

52. Thomson, S. V., Gouk, S. C., Vanneste, J. L., Hale, C. N., and Clark, R. G. 1993. The presence of streptomycin resistant strains of Erwinia amylovora in New Zealand. Acta Hortic. 338:223-230.

53. Van der Zwet, T., and Keil, H. L. 1979. Fire blight: a bacterial disease of rosaceous species. U. S. Dep. Agric. Agric. Handb. 510.

54. Vidaver, A. K. 2002. Use of antimicrobials in plant agriculture. Clin. Infect. Dis. 34:S107-S110.

55. Vila-Sanjurjo, A., Squires, C. L., and Dahlberg, A. E. 1999. Isolation of kasugamycin resistant mutants in the 16S ribosomal RNA of Escherichia coli. J. Mol. Biol. 293:1-8.

56. Wegener, H. C. 2003. Antibiotics in animal feed and their role in resistance development. Curr. Opin. Microbiol. 6:439-445.

57. Wilson, M., Epton, H. A. S., and Sigee, D. C. 1989. Erwinia amylovora infection of hawthorn blossom: II. The stigma. J. Phytopathol. 127:15-28.

58. Zhao, Y. F., Blumer, S. E., and Sundin, G. W. 2005. Identification of Erwinia amylovora genes induced during infection of immature pear tissue. J. Bacteriol. 187:8088-8103. 